UDK $811.163 .42^{\prime} 42$

811.163.42'282(497.5 Osijek)

Izvorni znanstveni rad

Rukopis primljen 21. II. 2018. Prihvaćen za tisak 29. III. 2018.

\title{
Mislav Benić
}

Odjel za onomastiku i etimologiju

Institut za hrvatski jezik i jezikoslovlje

Republike Austrije 16, HR-10000 Zagreb

mbenic@ihjj.hr

\section{PREPRIČAVANJE DISKURSA NA PRIMJERU OSJEČKOGA GOVORA ${ }^{1}$}

\begin{abstract}
Tema je članka prepričavanje diskursa (upravni i neupravni govor te neke bliske pojave). Autor ukratko izlaže u znatnoj mjeri vlastit pristup prepričavanju diskursa i ilustrira ga opisom toga fenomena u spontanom govoru osoba koje žive u Osijeku, a rođene su u Osijeku ili okolnim mjestima. U uvodu se daju osnovni podaci o predmetu i metodama istraživanja. Drugi dio rada sadrži kratak pregled pristupa prepričavanju diskursa u literaturi. U trećem se dijelu ukratko izlaže autorova koncepcija toga fenomena, a u sljedeća se četiri dijela rada opisuju načini prepričavanja diskursa u osječkom govoru: upravni govor, neupravni govor, priopćaj činjenice i polunavođenje. Slijedi dio u kojem se ukratko prikazuju neke oznake približnosti i skraćivanja originalnoga diskursa pri prepričavanju u osječkom govoru. Na kraju rada je zaključak, u kojem se navode bitniji rezultati.
\end{abstract}

\section{Uvod}

Pojam prepričavanje diskursa ovdje se upotrebljava kao zajednički naziv za upravni i neupravni govor te neke bliske pojave. ${ }^{2}$ Prepričavanju diskursa u literaturi nije posvećena velika pozornost. Postojeći domaći opisi prepričavanja dis-

1 Zahvalan sam svima koji su na ovaj ili onaj način doprinijeli članku: davanjem podataka, tehničkom pomoći, savjetom ili poticajem. To su u prvom redu moji informanti, koji su željeli ostati anonimni, a zatim abecedno prema prezimenima: Ankica Čilaš Šimpraga, Dijana Ćurković, Diana Didulica, Nada Filipin, Dubravka Ivšić Majić, Mate Kapović, Orsat Ligorio, David Mandić, Violeta Moretti, Mihail Vladimirovič Oslon, Vladimir Aleksandrovič Plungjan, Teo Radić, Željka Salopek i Mladen Uhlik.

2 Pojam se u onom opsegu u kojem se shvaća u ovom radu, definira pod 3. 
kursa nisu osobito detaljni. Osim toga, u skladu s tradicijom u kojoj se jezik promatra prvenstveno kao sustav, dok je jezična upotreba sekundarna ${ }^{3}$, u tim se opisima s jedne strane zanemaruju neki fenomeni koji postoje $\mathrm{u}$ jeziku, osobito $\mathrm{u}$ živu govoru ${ }^{4}$, a s druge se strane konstruiraju nepostojeće pojave, kao u sljedećim primjerima pretvorbe upravnoga govora u neupravni iz Hrvatske gramatike ${ }^{5}$ :

Spavajte, Maestro - umiruje ga Melkior. > Melkior umiruje Maestra neka Maestro spava.

Gospodine, ja vas opominjem! - povišenim glasom govorio je omalen čovjek. $>$ Omalen čovjek je povišenim glasom govorio da on njega, gospodina, opominje.

U respektabilnoj se stranoj literaturi (starijoj i novijoj) mogu naći opisi koji su detaljniji, sustavniji i usmjereniji na jezičnu upotrebu. Ipak, ni u suvremenoj stranoj literaturi nisam naišao na sustavan prikaz prepričavanja diskursa koji bi ujedno nudio dobar teorijski okvir za njegovo opisivanje. Naime, prepričavanje diskursa u mnogim dominantnim gramatičkim teorijama ostaje po strani jer se teško uklapa u njihovu sistematizaciju jezičnih pojava. Ta me situacija ponukala da pokušam stvoriti kakav-takav teorijski okvir koji bi omogućio kvalitetno opisivanje prepričavanja diskursa. Pomoću toga sam okvira analizirao prepričavanje diskursa u slobodnom spontanom govoru informanata iz Osijeka i okolnih mjesta. Cilj te analize nije bio samo stvaranje kraćega opisa prepričavanja diskursa na osječkom govornom području, nego i ilustracija te provjera upotrebljivosti i usavršavanje samoga teorijskoga okvira. Pristup se prepričavanju diskursa $u$ ovom radu temelji na načelima ruske funkcionalne gramatike ${ }^{6}$ : predmet je definiran prema funkciji, analizirana je građa te su na temelju formalnih osobina izdvojeni tipovi prepričavanja diskursa, a zatim su uspoređeni po funkciji. Slično je tekla i analiza svakoga pojedinoga tipa. Ipak, budući da je riječ o analizi govornoga jezika pri kojoj se pozornost obraća između ostaloga na funkciju jezičnih fenomena i interakciju sugovornika, sam se pristup može smatrati i konverzacijskom analizom, tim više što u samoj Teoriji funkcionalne gramatike evidencijalnost nije opisana.

3 Spomenuta se tradicija u nedostatku prikladnijega epiteta obično etiketira kao strukturalistička.

4 Cinjenica da je u prvom planu jezik kao sustav, naravno, ne znači da se jezična upotreba uopće ne promatra, nego da mnogi njezini aspekti autore ne zanimaju, i da se oni u donošenju pravila mogu od nje apstrahirati. Osim toga, autori rade isključivo s pismenom građom, a usmena građa ostaje izvan vidokruga.

5 Barić i dr. 1997: 529. Radi kratkoće se navode samo primjeri bez popratnoga teksta.

6 V. Бондарко 1987: 3 sqq. Osobito je u pristupu ruske funkcionalne gramatike to što za polazište pri opisivanju jezičnih fenomena uzima značenje/funkciju, pa se od značenja kreće prema formi a potom, po potrebi, obratno, usp. Бондарко 1987: 14. Takav se pristup u nekim slučajevima - a takav je slučaj i prepričavanje diskursa - može pokazati vrlo korisnim, osobito ako se imaju u vidu moguća kasnija tipološka uspoređivanja i poopćavanja. 
Podaci o prepričavanju diskursa u osječkom govoru dobiveni su analizom osam sati snimljenoga spontanoga govora. Riječ je o pet snimaka različite duljine. Sniman je razgovor za stolom na razne teme. Da bi podaci iz govora bili što spontaniji, informanti nisu upozoreni da će biti snimani, nego su naknadno (neposredno nakon snimanja) obaviješteni o snimanju i njegovoj svrsi. Objašnjeno im je na koji se način namjerava upotrijebiti snimljena građa ako daju suglasnost za to, odnosno da će snimka biti odmah uništena ako netko od njih nije suglasan da se upotrijebi. U istraživanju je sudjelovalo dvanaest osoba. Među njima je devet žena i tri muškarca u dobi od 21 do 76 godina, ali najviše materijala potječe od informanata između 30 i 55 godina. Informanti su većinom srednje stručne spreme. Svi žive u Osijeku, ali ih je polovica rođena u okolnim mjestima. Između informanata rođenih u Osijeku i u okolici nisu uočene bitne razlike u prepričavanju diskursa koje bi bile uvjetovane mjestom rođenja, pa se njihov govor u tom smislu može smatrati jedinstvenim i obuhvatiti nazivom osječki govor. Štoviše, ono što u pogledu prepričavanja diskursa vrijedi za Osijek, svakako većinom vrijedi i za mnoge druge istočnoslavonske govore, a u nešto manjoj mjeri i šire. Podatke dobivene analizom govora informanata mogao sam lakše procijeniti, ocijeniti i dopuniti gdje je bilo potrebno, zahvaljujući tomu što sam i sâm rođen i odrastao u Osijeku. Ipak, premda je opis prepričavanja diskursa u poglavljima 4.-8. relevantan za osječki govor, on se ne može smatrati iscrpnim. Osim toga, iako se gdjekad daje poneki sociolingvistički podatak, opis nipošto nije sociolingvistički jer se zbog skromnosti korpusa varijable kao dob, spol, obrazovanje itd. većinom ne uzimaju u obzir.

Govor se informanata može smatrati relativno jedinstvenim ne samo s obzirom na prepričavanje diskursa, nego i s obzirom na ostale osobine. Ovdje nema smisla ulaziti u podrobnosti osječkoga govora, ali ću ipak spomenuti tri osobitosti koje su u zapisu govora najuočljivije. Dugi se jat u osječkom govoru ne odražava kao ije ili diftong, nego kao je, pa se tako i zapisuje ${ }^{7}$; informanti, kao i većina osječkih govornika, u izgovoru ne razlikuju foneme $\check{c}$ i ć te $d \check{\text { i }} d$, nego na njihovu mjestu imaju po jedan fonem, koji se ovdje bilježi kao $\check{c}$, odnosno $d$; akcentuacija većine informanata je novoštokavska osječka akcentuacija, u kojoj se zanaglasne duljine čuvaju u pravilu samo neposredno iza uzlaznih naglasaka (ponekad se ne čuvaju ni ondje) ${ }^{8}$, a dvoje najstarijih informanata ima i neke elemente staroštokavske akcentuacije. Primjere sam spontanoga osječkoga govora nastojao prenijeti onoliko vjerno koliko sam smatrao relevantnim za ovaj

${ }^{7}$ L i $n$ zajedno s odrazom dugoga jata koji im slijedi, obično se odražavaju kao l̦e i ńe. Umjesto znakova $l$ i $n$ u primjerima govora iz tehničkih razloga upotrebljavam $l j$ i $n j$. Skupina $l j$ i $n j \mathrm{u}$ primjerima nema, pa upotreba monograma $l$ i $n$ n nije nužna.

8 Detaljnije o osječkoj akcentuaciji v. Benić 2007. 
rad, a možda i nešto vjernije. S tim se u skladu u primjerima označava fonološka prozodija, a označavaju se još neke značajke govornoga jezika. Tako se ponekad uobičajenim znakovima za fonološke naglaske i duljinu označava i nefonološka prozodija, stanka se označava dvjema točkama (..), fonacija znakom šva (ə), a samoispravljanje u govoru znakom $>$. Osim znakova za četiri novoštokavska naglaska, novi akut i duljinu, u primjerima dolaze još dvije prozodijske oznake: ^ (označava poludugi silazni naglasak, aloton kratkosilaznoga) i '(označava poludugi uzlazni naglasak, aloton kratkouzlaznoga). Tekst se primjera prenosi točno, jedino je većina antroponima radi korektnosti prema informantima i ostalim osobama koje se u primjerima spominju, morala biti zamijenjena drugima. ${ }^{9}$

\section{Prepričavanje diskursa u literaturi}

U kroatistici, koliko mi je poznato, ne postoji jedinstven naziv za pojave koje ovdje obuhvaćam terminom prepričavanje diskursa, pa se različiti načini prepričavanja diskursa obično obuhvaćaju nazivom upravni i neupravni govor. Tako se u Katičićevoj sintaksi i gramatici Barić i sur. ${ }^{10}$ pod naslovom Upravni i neupravni govor ne obrađuju samo upravni i neupravni govor, nego i fenomen koji se ondje naziva slobodni neupravni govor. Slobodnim se neupravnim govorom u oba priručnika naziva zapravo nekoliko tipova prepričavanja diskursa (najmanje dva), koji neke osobine dijele s neupravnim, a neke s upravnim govorom. ${ }^{11}$ Što se pak tiče dvaju osnovnih tipova prepričavanja diskursa, u navedenim se priručnicima daje tradicionalna definicija upravnoga i neupravnoga govora, po kojoj je upravni govor navođenje tuđih riječi upravo onako kako su izgovorene, dok se u neupravnom govoru sadržaj tuđih riječi preoblikuje i kao zavisna rečenica uvrštava u glavnu. ${ }^{12}$ Nakon opisa nekih osobina upravnoga i neupravnoga govora, spomenute dvije gramatike daju pravila pretvorbe upravnoga govora $u$ neupravni. Ono što služi kao izvor neupravnoga ili upravnoga govora naziva se u Katičića te Barić i suradnika tuđim riječima ili tuđim govorom.

$\mathrm{U}$ istom se značenju termin tuđi govor (чужая речь) upotrebljava i u rusistici, a prepričavanje se diskursa označava nazivom prenošenje tuđega go-

\footnotetext{
9 Među zamjenskim antroponimima nema takvih za koje mi ne bi bili poznati osječki nositelji. Naglasci su i deklinacija tih antroponima u ovom radu onakvi kakvi su uobičajeni u osječkom govoru.

10 Katičić 1991: 344 sqq., Barić i dr. 1997: 525 sqq.

11 Usp. Katičić 1991: 354-356. Može se reći da se u oba priručnika prepričavanje diskursa opisuje na isti način uz napomenu da je u Barić i sur. opis nešto sažetiji. U ostalim se pak konzultiranim našim gramatikama ovaj fenomen ili uopće ne obrađuje (Maretić 1899, Raguž 1997, Silić i Pranjković 2005) ili se obrađuje relativno slično kao u Barić i sur., ali manje iscrpno (Brabec, Hraste i Živković 1968, Težak i Babić 2004, Bičanić 2013), uz napomenu da slobodni neupravni govor poznaje samo posljednja navedena gramatika.

12 Usp. Katičić 1991: 344 te Barić $i$ dr. 1997: 525.
} 
vora (передача чужой речи), ali i samim terminom tuđi govor. ${ }^{13} \mathrm{U}$ Ruskoj gramatici (Шведова 1980: $§ 1803$ ) napominje se da se termin tuđi govor odnosi na reproducirani tuđi, ali i na reproducirani vlastiti govor. I u literaturi na ruskom razlikuju se obično tri tipa prenošenja tuđega govora: upravni govor (прямая речь), neupravni govor (косвенная речь) i nepravi upravni govor (несобственно-прямая речь ${ }^{14}$ ). Osim nepravoga upravnoga govora u ruskom postoje još neki substandardni prijelazni oblici između neupravnoga i upravnoga govora, koji se ukratko obrađuju u Шведова 1980: § 2806, ali se ondje nikako ne imenuju. O upravnom se govoru u Диброва 2008 (589) tvrdi da se tradicionalno definira kao doslovna reprodukcija tuđega govora, ali da je takva definicija pogrešna, što je lako dokazano usporedbom tri različite reprodukcije jednoga Kutuzovljeva govora u tri teksta (jednom povijesnom i dva književna) ${ }^{15}$. Tradicionalna se zabluda može lako objasniti upravo činjenicom da se prepričavanje diskursa proučava, nažalost, gotovo isključivo na građi iz književnih tekstova, pri čem se nekako samo po sebi razumije da pripovjedači riječi svojih fiktivnih likova u upravnom govoru navode upravo onako kako su tobože bile izrečene. Međutim, pri bavljenju građom iz živa govora odmah postaje jasno da upravni govor ne može biti isto što i doslovno navođenje, ako ni zbog čega drugoga, a ono zato što prosječan čovjek nije sposoban spontano doslovno zapamtiti sve što reproducira u upravnom govoru. Da upravni govor ne može biti »mimikrija originalnoga iskaza« naglašava se i u članku Попова 2009: 66 sq., gdje se tomu u potvrdu navode i dva njemačka primjera iz živoga govora: original i reprodukcija toga originala u upravnom govoru. Dakle, osnovna razlika između upravnoga i neupravnoga govora očito nije u (ne)doslovnosti reproduciranja originala, nego u nečem drugom. U Шведова 1980: § 2085 ne govori se, kao u našim gramatikama, o pretvorbi upravnoga govora u neupravni, nego o preo-

13 Usp. Шведова 1980: § 2803 і Диброва 2008: 587. U posljednjem se djelu daje dosta dobar sažet prikaz shvaćanja prepričavanja diskursa u rusistici s najosnovnijom literaturom.

14 Danas je uobičajen upravo taj termin, ali jedan je od starijih naziva istoga pojma termin свободная косвенная речь, tj. slobodni neupravni govor (usp. Диброва 2008: 595), koji nalazimo i u našim gramatikama. Pojednostavnjeno bi se moglo reći da je nepravi upravni govor upravni govor u kojem govornik nije u prvom, nego u trećem licu. On se u rusistici obično povezuje s načinom pripovijedanja koji se zove slobodni neupravni diskurs (rus. свободный косвенньй дискурс, eng. free indirect discourse), pripovijedanjem u trećem licu u kojem u prvom planu nije pripovjedač, nego lik (unutrašnji monolog u trećem licu i slične pojave): v. Диброва 2008: 595 sq. і Падучева 2010: 204, 337 i 344. U hrvatskim se pak gramatikama slobodnim neupravnim govorom nazivaju i takve, ali i drukčije pojave, kao što su primjeri slični tipičnomu neupravnomu govoru, ali s izostavljenom glavnom rečenicom, usp. iz Katičić 1991: 356: Ne daju mi bicikl jer da sam premalen.

15 Doslovna se reprodukcija diskursa u Диброва 2008: 601 zove citiranje (цитирование ili цитаичя). Doduše, pitanje je bi li podvrstom citiranja ili nečim drugim trebalo smatrati što doslovnije prevođenje nekoga izraza na drugi jezik (npr. kada nekoj osobi želimo što točnije prenijeti neku frazu ili duži tekst izvorno izrečen na jeziku koji ta osoba ne zna). 
blikovanju izvorne izjave (»первичного сообщения«) u neupravni govor, što s teorijskoga gledišta ima znatno više smisla jer između upravnoga i neupravnoga govora u stvarnosti ne postoji neposredan odnos, nego je taj odnos posredan utoliko što se oba govora, na različit način, izvode iz izvornoga diskursa.

U talijanistici se za prepričavanje diskursa upotrebljava termin preneseni diskurs (discorso riportato ${ }^{16}$ ). Upravo prema tom terminu stvorio sam termin prepričavanje diskursa. Termin prepričavanje diskursa, kao i njegov izvornik discorso riportato, smatram prihvatljivijim od ranije spomenutih naziva iz sljedećih razloga. Kao prvo, termin prepričavanje diskursa, za razliku od termina upravni i neupravni govor, ne označava dvije najtipičnije realizacije fenomena, nego fenomen označava kao jedinstven pojam. Kao drugo, termin prepričavanje diskursa relativno točno odražava fenomen koji označava. Ta se točnost s jedne strane očituje u tom, što kad govorimo o prepričavanju diskursa, ne moramo, kao u slučaju prenošenja tuđega govora, naglašavati da se pod tuđim govorom podrazumijeva i vlastiti govor. S druge pak strane, riječ diskurs jednako podrazumijeva usmenu i pismenu realizaciju jezika, dok riječ govor, bez obzira na to što sosirovski govor (parole) označava bilo koju realizaciju jezičnoga sustava (langue), ipak primarno asociramo s usmenom realizacijom jezika. ${ }^{17} \mathrm{U}$ Velikoj talijanskoj konzultacijskoj gramatici prenesenim se diskursom smatraju razni načini na koje se mogu navoditi iskazi izrečeni ili koji bi se mogli izreći u govornom činu različitu od govornoga čina navođenja. ${ }^{18} \mathrm{U}$ istoj se gramatici (str. 432) razlikuje pet takvih

16 Usp. na primjer Renzi, Salvi, Cardinaletti 2008: 429. Kao ekvivalenti ondje se navode i termini discorso riferito, citato, riprodotto. $\mathrm{U}$ engleskom pak reported speech tradicionalno kao i indirect speech označava samo neupravni govor, direct speech označava upravni govor, dok se prepričavanje diskursa obično označava terminom quotation, usp. na primjer Forsyth 1970: 69 i Evans 2013. Ipak, u Evans 2013 (67 i posvuda) razlikuju se primary speech events (situacija izvornoga govora) i reported speech events (situacija prepričanoga govora), a također u značenju prepričani diskurs/govor dolazi reported speech.

17 Unatoč tomu, discorso riportato ne prevodim kao prenošenje, nego kao prepričavanje diskursa smatrajući da riječ prenošenje u ovom kontekstu nije u duhu hrvatskoga jezika. S druge strane, i u svakodnevnom se govoru prepričavanje može shvatiti i kao usmeno i kao pismeno prepričavanje, ali, kao što će se kasnije vidjeti, prepričavanje diskursa ne uključuje samo verbalnu reprodukciju. Ovdje govorim upravo o prepričavanju diskursa, a ne o prepričanom diskursu, zato što je predmet istraživanja ipak proces kojim se od originalnoga diskursa dobiva prepriča$\mathrm{ni}$, tj. odnos originala i reprodukcije, a ne isključivo rezultat toga procesa. Za terminom prepričani diskurs u teoriji koju nudim, barem zasad, ne postoji potreba jer se rezultat prepričavanja diskursa ovdje imenuje kraćim i praktičnijim terminom prijekaz. Termin citiranje prema engleskom quotation također smatram neodgovarajućim jer su neki tipovi prepričavanja diskursa (ponajprije priopćaj činjenice) vrlo daleki od onoga što se obično poima kao citiranje.

$18 \gg$ Per discorso riportato si intendono i vari modi (...) in cui si possono citare enunciati prodotti o da produrre in un atto di enunciazione diverso da quello che dà luogo alla citazione." Renzi, Salvi, Cardinaletti 2008: 429. 
načina, tj. pet osnovnih tipova prepričavanja diskursa ${ }^{19}$ : upravni govor (discorso diretto), neupravni govor (discorso indiretto), slobodni neupravni govor (discorso/stile indiretto libero/semi-indiretto), poluupravni govor (discorso semidiretto) i slobodni upravni govor (discorso diretto libero). Prva tri tipa po funkciji odgovaraju trima tipovima u rusistici, četvrti je tip neupravni govor bez slaganja vremena $^{20}$, dok je posljednji tip podvrsta upravnoga govora (duže dionice u upravnom govoru bez uvodnoga izraza - unutrašnji monolozi u književnim tekstovima i sl.). Osim toga, kao podvrsta neupravnoga govora spominje se tzv. narativizirano navođenje (citazione narrativizzata) ili nezavisni/narativizirani neupravni govor (discorso indiretto non subordinato/narrativizzato), tj. rečenice deiktički potpuno prilagođene situaciji reprodukcije s umetnutim uvodnim izrazom ${ }^{21}$. O neupravnom se govoru u istoj gramatici (str. 438) kaže da se prezentira kao da je doslovan navod, ali da je pitanje vjernosti upravnoga govora originalu za gramatiku irelevantno. ${ }^{22} \mathrm{U}$ ovoj je gramatici prepričavanje diskursa općenito prikazano temeljitije nego u bilo kojem od ranije navedenih priručnika.

Zanimljivo je da se u njoj, ako brojimo i narativizirano navođenje, izdvaja pet tipova prepričavanja diskursa, koji bi se mogli izdvojiti i u hrvatskom ili ruskom standardnom jeziku, iako hrvatske i ruske gramatike izdvajaju samo tri tipa. Naime, i u pojedinim jezicima, a osobito tipološki gledano u jezicima općenito, postoji relativno velik broj varijanata i kombinacija između upravnoga govora i druge krajnosti deiktički potpuno prilagođene situaciji reprodukcije, i te je varijante teško razgraničiti. Dobar se uvid u situaciju dobiva iz tipološki orijentiranoga članka Evans 2013. ${ }^{23}$ Ondje se postuliraju tri kanonska tipa prepričavanja diskursa: kanonski upravni govor (canonical direct speech), kanonski neupravni govor (canonical indirect speech) i kanonski dvoperspektivni govor ( $\mathrm{ca}$ nonical biperspectival speech). U kanonskom je upravnom govoru deiksa potpuno orijentirana na situaciju izvornoga govora. On je dobro posvjedočen u jezicima svijeta (za neke bi se gotovo moglo reći da imaju samo upravni govor). U kanonskom je neupravnom govoru deiksa potpuno orijentirana na situaciju prepričanoga govora. On je prema Evansu u jezicima svijeta slabo posvjedočen, a znatno su bolje posvjedočeni nekanonski tipovi u kojima su jedni deiktici orijentirani na situaciju izvornoga, a drugi na situaciju prepričanoga govora. ${ }^{24} \mathrm{Ka}-$

19 Na str. 429 osnovnima se nazivaju samo tri prva tipa.

20 U slavenskim jezicima u neupravnom govoru nema slaganja vremena, pa je za njih razlikovanje drugoga i četvrtoga tipa irelevantno.

21 Rečenice kao: To je, kako on kaže, vrlo nezgodno.

22 Usp. i Evans 2013: 72.

23 V. 95 sq. i posvuda.

24 Tako je u hrvatskom neupravnom govoru glagolsko vrijeme orijentirano na situaciju originalnoga iskaza, dok su lične zamjenice orijentirane na situaciju reprodukcije. 
nonski dvoperspektivni govor $\mathrm{u}$ jezicima nije posvjedočen, a to bi bio reproducirani govor u kojem bi svi deiktici bili ujedno orijentirani na obje situacije. Međutim, mješoviti su tipovi s dvoperspektivnom deiksom posvjedočeni. ${ }^{25}$ Tipologija je prepričavanja diskursa zasad ipak u znatnoj mjeri neistraženo područje.

\section{Koncepcija prepričavanja diskursa u ovom radu i osnovni tipovi prepričavanja diskursa u osječkom govoru}

Prepričavanjem se diskursa u ovom radu smatraju razni načini pretežno ili potpuno verbalne reprodukcije pretežno ili potpuno verbalnoga sadržaja, pri čem je verbalna sastavnica obavezna, a posrednik je između izvornoga sadržaja i reprodukcije, ako je riječ o stvarnom izvornom sadržaju koji vremenski prethodi reprodukciji, obavezno ljudsko pamćenje, ponajprije dugoročno. Obavezno posredovanje ljudskoga pamćenja iz okvira prepričavanja diskursa isključuje pojave kao što su jeka, pričanje papagaja, tiskanje knjiga, reprodukcija snimljenoga govora, presnimavanje i razne druge vrste kopiranja, a barem donekle isključuje i čitanje naglas. Pojam reprodukcija podrazumijeva odnos prijekaza prema originalu (za termine v. idući odjeljak), pa makar original bio samo potencijalan ili čak nulti ili fiktivan, a sam odnos prema originalu skriven, $i$ isključuje više ili manje slučajno poklapanje dvaju sadržaja. Doduše, ni prepričavanje diskursa, kao ni ostale pojave u jeziku, nema jasne granice. Tako se o pojavama kao što su, recimo, recitiranje pjesme napamet, ponavljanje za nekim te konsekutivno ili kakvo drukčije prevođenje, teoretski može govoriti u sklopu teme prepričavanje diskursa, ali one su svakako daleko od toga da bi se mogle smatrati tipičnim prepričavanjem diskursa. Tipičnim bi se moglo smatrati takvo prepričavanje diskursa u kojem se adresatu prenosi neki pretežno verbalni sadržaj koji je originalno na jeziku svojstvenu cijeloj situaciji prijekaza ${ }^{26}$, s ciljem da bi ga se o tom sadržaju obavijestilo ili da bi ga se na nj podsjetilo. Od takva prepričavanja diskursa proteže se kontinuum sve manje tipičnih varijacija do onih najmanje tipičnih. Prepričavanje diskursa, prema tome, ima najviše smisla promatrati kao svojevrsno funkcionalno-semantičko polje relativno nejasnih granica ${ }^{27}$.

${ }_{25}$ Takva je, na primjer, deiksa glagolskih vremena pri slaganju vremena u engleskom, francuskom i talijanskom neupravnom govoru.

${ }_{26} \mathrm{Tj}$. u situaciji u kojoj se događa original, osnovni je jezik sporazumijevanja isti kao i u situaciji u kojoj se događa prijekaz.

27 Za termin funkcionalno-semantičko polje v. Бондарко 1987: 3. Prepričavanje je diskursa zapravo samo dio funkcionalno-semantičkoga polja evidencijalnosti, ali metodologija koja se primjenjuje na proučavanje pojedinih funkcionalno-semantičkih polja, može se primijeniti i na proučavanje pojedinih dijelova tih polja. 
Prepričavanje diskursa ima najmanje dvije osnovne faze: original (izvorni diskurs) i prijekaz (prepričani diskurs). ${ }^{28}$ Prepričavanje je diskursa rekurzivna pojava, pa faza može biti i više od dvije, tj. prijekaz može poslužiti kao original za ponovno prepričavanje. Svaka faza ima svoje koordinate i svoj sadržaj. Koordinate su sudionici komunikacije (adresant(i) i adresat(i) ${ }^{29}$ ), te s njima povezani prostor, vrijeme ${ }^{30}$ i eventualno još neki parametri. Sadržaj je pak pretežno verbalna obavijest koju adresanti prenose adresatima. Sadržaj je prijekaza svojevrsna reprodukcija sadržaja originala. Prijekaz obično sadrži i markere prijekaza, tj. elemente koji naznačavaju da je riječ upravo o prijekazu.

Vrijeme originala obično prethodi vremenu prijekaza, ali može mu i slijediti (recimo, kad nekomu savjetujemo što da kaže - u tom je slučaju original potencijalan). Međutim, vrijeme originala i prijekaza, za razliku od prostora, nikako se ne mogu potpuno poklapati (potpunoga poklapanja nema ni pri simultanom prevođenju). Sadržaj originala može biti različite duljine i funkcije te može obuhvaćati diskurs samo jedne osobe (dio dijaloga ili monolog) ili diskurs u kojem sudionici komunikacije izmjenjuju uloge. Puni se sadržaj originala sastoji od jezgre i ovojnice. Jezgra i ovojnica su apstraktni pojmovi, što znači da ih je u konkretnim primjerima nemoguće razdvojiti. Jezgra je smisao poruke neovisan o formi i uvjetima u kojim se ona priopćava. Za razliku od propozicije jezgra ima modalna obilježja te može označavati i tvrdnju i zahtjev i pitanje. Ovojnicu pak čine orijentacija i način priopćaja. Orijentacijom se smatraju komunikacijski, socijalni, vremenski i prostorni odnosi izrečeni pomoću koordinata, tj. izraženi deiksom. Načinom se priopćaja ovdje smatra nekoliko donekle raznorodnih elemenata, od kojih su najosnovniji sljedeći: 1. jezik, dijalekt, idiolekt i sl. na kojem je poruka izrečena; 2 . ekspresivnost; 3 . govorne vrednote i slične pojave. Elementima se načina priopćaja mogu smatrati i neke osobitosti diskursa kao što su stil, kronologija pripovijedanja itd., iako bi se te pojave, barem djelomično, mogle pripisivati i jezgri, jer zapravo nije sasvim jasno gdje bi trebalo povući granicu između načina priopćaja i jezgre. Sadržaj prijekaza nije kopija, nego u pravilu više ili manje netočan odraz punoga sadržaja originala

${ }_{28}$ Mogući su i drugi slični termini, od kojih su neki ranije spomenuti, ali u daljnjem tekstu preferiram upravo nazive original i prijekaz. Između originala i prijekaza mogla bi se po potrebi postulirati još najmanje jedna osnovna faza, tj. faza pohrane, za vrijeme koje se odraz originala nalazi u ljudskom pamćenju, ali takve potrebe u ovom radu nema.

${ }_{29}$ Adresant nije isto što i govornik jer je adresant pošiljatelj poruke na ljudskom jeziku bez obzira na medij (govor, pismo ili nešto treće), a adresat nije isto što i slušatelj zato što je adresat onaj komu je poruka namijenjena (osobito ako je ta namjena eksplicitna), i to poruka na ljudskom jeziku bez obzira na medij i bez obzira na to doživljava li je on ili ne, dok je slušatelj onaj tko sluša govor bez obzira na to je li mu upućen ili ne.

${ }^{30}$ U komunikaciji na daljinu i u pismenoj komunikaciji uz različite se sudionike komunikacije mogu vezati različiti prostori i različita vremena. 
ili samo njegove jezgre ${ }^{31}$. Do netočnosti obično dolazi spontano iz raznih razloga, ali one se u prijekaz mogu unositi i svjesno (ako prekazivač (adresant prijekaza) iz nekih razloga želi »dotjerati« original). Doduše, prijekaz može postojati i onda kad original ne postoji čak ni kao potencija. Postoje dva takva slučaja: nulti i fiktivni original. O nultom je originalu riječ kad se govori da netko nešto nije ili ne bi rekao ili neće reći i sl. te kad prekazivač nekoj osobi govori štö je ona u određenoj situaciji trebala reći. Original je fiktivan kad prekazivač laže da je netko nešto rekao ili da je nešto sâm rekao, u književnoj fikciji i sl. Premda o stupnju vjernosti prijekaza originalu ima smisla govoriti samo u slučaju stvarnih, a ne u slučaju potencijalnih, nultih i fiktivnih originala, odnos je prijekaza prema originalu općenito bitan u proučavanju prepričavanja diskursa. Markeri prijekaza mogu biti neposredni i posredni. Neposrednim se markerima prijekaza mogu smatrati gramatički pokazatelji reportativa ${ }^{32}$, riječi kao navodno, glagoli govorenja i njima slični glagoli te naznake originalnih adresanata i adresata. Posrednim se markerima prijekaza mogu smatrati ponajprije neki elementi ovojnice preneseni iz originala, npr. imitiranje govora originalnoga adresanta i čuvanje originalne deikse. Međutim, u nekim se slučajevima samo prema općem znanju ili širem kontekstu može zaključiti ili barem nagađati da je riječ o prijekazu, a ne o originalu. ${ }^{33}$

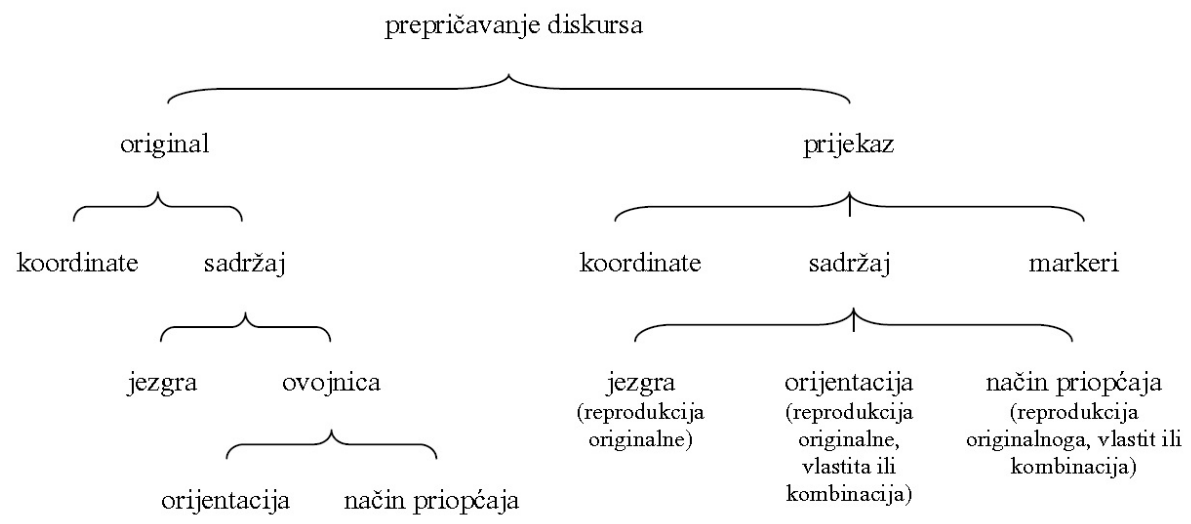

Slika 1. Shematski prikaz prepričavanja diskursa.

${ }_{31}$ S obzirom na to da sama jezgra ne može biti izrečena ili napisana zbog svoje apstraktnosti, ona u tom drugom slučaju mora dobiti novu ovojnicu, koja se može djelomično poklapati sa starom.

32 U hrvatskom reportativa (u upotrebi su i drugi termini kao citativ i renarativ), tj. glagolskoga načina kojim se označava da je govornik obavijest dobio od druge osobe, nema, ali on postoji, primjerice, u kečuanskom i latvijskom usp. Plungjan 2016: 406 i 416.

${ }_{33}$ Naravno, mogući su i prijekazi za koje slušatelj neće pretpostaviti da su prijekazi. 
Razni se načini prepričavanja diskursa izdvajaju s jedne strane na temelju parametara povezanih s odnosom originala i prijekaza (dio originala koji se prenosi u prijekaz, tipovi originala koji se mogu prenositi u prijekaz, i sl.) te, s druge strane, na temelju formalnih osobina prijekaza kao što su markiranje prijekaza, upotreba deikse i dr. Tako bi se u osječkom govoru mogla izdvojiti četiri osnovna načina prepričavanja diskursa: upravni govor, neupravni govor, polunavođenje i priopćaj činjenice. U upravnom je govoru prijekaz svojevrsna replika originala. On, s tim u vezi, reprezentira više ili manje puni sadržaj originala, iako ga uglavnom ne predaje sasvim vjerno. U upravnom se govoru original obično u većem ili manjem stupnju inscenira. S funkcijom inscenacije originala povezana je i činjenica da je upravni govor jedini tip prepričavanja diskursa koji je dobro prilagođen dijalogu. Neupravni pak govor original ne replicira nego ponajprije prenosi ono što se originalom želi reći, tj. reproducira prvenstveno jezgru sadržaja originala, a u znatno manjoj mjeri elemente načina priopćaja, dok se orijentacija uglavnom ne reproducira, nego se original prepričava iz perspektive situacije prijekaza. Upravni i neupravni govor mogli bi se usporediti s govornim i pripovjednim režimom interpretacije $\mathrm{e}^{34}$, odnosno govornim i pripovjednim stilom. Upravni bi se govor mogao smatrati pripovjednim režimom interpretacije originalnoga diskursa, a neupravni govornim. Kao svaka usporedba, i ova usporedba vrijedi samo donekle. U upravnom je i neupravnom govoru veza s originalom čvrsta, tj. originalna se izjava prezentira upravo kao izjava. Pri polunavođenju je veza s originalom slabija. Naime, polunavođenje ima neke karakteristike iz kojih je jasno vidljiv odnos prema originalu, ali isto tako, ima i neke karakteristike koje ga zbližavaju s priopćajem činjenice. Priopćaj se činjenice, koliko mi je poznato, obično ne izdvaja kao tip prepričavanja diskursa, ali je po mom mišljenju taj tip nužno izdvajati, osobito ako se u proučavanju prepričavanja diskursa ide od funkcije i značenja prema formi i ako se pri opisivanju prepričavanja diskursa u jednom govoru ili jeziku imaju u vidu moguće kasnije tipološke usporedbe s prepričavanjem diskursa u drugim govorima i jezicima. U priopćaju se činjenice veza s originalom gubi ili barem odlazi u pozadinu. Naime, uz stanovite ograde vrijedi da se jezgra originala pri priopćaju činjenice prenosi na isti način na koji bi se mogla prenijeti i situacija koju je govornik sâm doživio, dok adresati o izvoru obavijesti nerijetko sude na

34 O terminima v. Падучева 2010: 13 sq. U pripovjednom režimu, za razliku od govornoga, ne postoji odnos između teksta i govorne situacije. Drugim riječima, pripovjedni je režim također svojevrsna inscenacija pripovijedanih događaja: recipijent, odnosno adresat, se prenosi u situaciju o kojoj se pripovijeda, pri čem se gubi veza sa samom situacijom pripovijedanja. Zato je za pripovjedni režim karakterističan upravo tzv. historijski prezent, koji bi se zapravo trebao prevoditi kao pripovjedni prezent (grč. i $\sigma \tau o \rho \varepsilon \tilde{\imath} v$ - pripovijedati). U govornom se pak režimu događaji pripovijedaju strogo iz perspektive govorne situacije. 
temelju vlastitih znanja. ${ }^{35}$ Različiti tipovi prepričavanja diskursa imaju različitu funkciju. Ukratko se o toj razlici može reći sljedeće. Za koji će se tip prepričavanja diskursa prekazivač odlučiti ovisi o tom je li mu bitno da dočara sam original ili samo da prenese njegov smisao te, ukoliko nastoji prenijeti samo smisao originala, je li mu zgodnije da ga prezentira kao izjavu, kao interpretaciju izjave ili kao činjenicu. Što je prekazivaču »bitno« i »zgodno«, ovisi o više faktora, od kojih su vjerojatno najbitniji sljedeći: osobine originala (dužina, modalnost, je li original dijaloški ili monološki, sadrži li ovojnica originala neke elemente koje je važno prenijeti), svrha prepričavanja diskursa (kontekst u koji se uklapa prijekaz), praksa u određenu jeziku, govoru i stilu te sklonost prekazivača k dramatizaciji. Da bi se točnije utvrdile specifičnosti upotrebe pojedinih tipova, valjalo bi provesti opsežno istraživanje, koje nadilazi granice ovoga rada. U nastavku se detaljnije prikazuju načini prepričavanja diskursa u govoru Osijeka i okolice.

\section{Upravni govor}

U osječkom se govoru upravni govor upotrebljava vrlo često: u analiziranoj je građi češći nego bilo koji drugi tip prepričavanja diskursa. Situacija je takva ili slična po svoj prilici i u usmenom govoru općenito, barem u većini slučajeva. Kao što je rečeno, prijekaz je u upravnom govoru svojevrsna replika originala. To nipošto ne znači da je on vjerna kopija originala, nego samo to da se $u$ upravnom govoru reproduciraju i jezgra i ovojnica originala, iako ta reprodukcija može biti i nepotpuna i netočna. Prema tome, možda bi točnije bilo reći da se upravni govor prezentira kao svojevrsna replika originala nego da on to jest. Sam tekst originala može se prenijeti sasvim vjerno, ali to često nije slučaj, osobito ako je riječ o dužim odsječcima diskursa i ako je vremenska udaljenost između originala i prijekaza relativno velika ili ako govorniku općenito iz nekih razloga nije bitno da neki tekst prenese doslovno. Moguće razlike između dvaju prijekaza jednoga originala dobro ilustrira sljedeći primjer.

1. I säd, Jäsna, zòvē ti tätu u ònū drügu söbu di je pikâdo... — ${ }^{36} \hat{E}$, dâdâdâdâ. — Käo: .. Znâš, kâže, ëvo ti, dâj Marinëli za pîvo: nè mogu tämo pred Nádōm da nè čuje, kâže: nè mogu jâ njôj üvjek bòbiflips kupòvat. $\hat{E}$, a näglās. (...) Nije, nego ònā (sic), .. a vëč òna zújila, nâš ovàkō, òna šêpa (prekazivač oponaša hod adresantice originala): ovako, .. ödi. (...) Čěk: èvo, kaže, ëvo. Äj, kaže,

35 Tako, ako netko kaže Zahladjelo je., pretpostavljamo da se on u to sâm uvjerio, a ako kaže Umro je X. Y., obično pretpostavljamo da je to čuo ili pročitao.

${ }_{36}$ Crticom dvostruke dužine označavam smjenu stvarnih govornika u primjeru (ako je govornika u primjeru više od dva, označavam ih slovima A., B., C. itd.), a crticom uobičajene dužine po potrebi označavam smjenu govornika originalnoga diskursa unutar prijekaza. 
mölim te, dâj Marinëli tê nôvce, kâže, nek donèsē ljêpo čëtri pîva, kaže... Ma nè mogu, ak büdem tämo dávala, kaže, pred njôm, onda če Náda ödma tráżit za smöki. A dëre se, léga, a vráta òtvorena: tô se čùje...

Original se po svoj prilici od obaju navedenih prijekaza razlikuje podjednako kao što se prijekazi razlikuju međusobno. Već je spomenuto da original pri prepričavanju diskursa nije uvijek stvaran, nego da postoje također fiktivni, nulti i potencijalni originali. To vrijedi prije svega za upravni i neupravni govor, dok u ostalim tipovima prepričavanja diskursa nema nultih i potencijalnih originala. Original je fiktivan u 2. primjeru, dok su originali u 3. i 4. primjeru nulti. U 5. se pak i 6. primjeru uz po jedan prijekaz stvarnoga originala nalaze po dva prijekaza potencijalnoga originala.

2. A.: Štö me pèčè òvō! - B.: Štä te pèčēe - A.: A òvō na rúci. - C.: Zàrezala se jùčè. - B.: Dädada, tô sam cuüla. - C.: A štä je bílo, Bêbo? - Mä, kâže, kod Nèvene koláče kad sam rëzala, pa sam se pòsjekla kòd njē. — B.: Ä nije, nije. - C.: Hahahaha.

3. (...) Tô si trëbala rëči da sam > nísam bölesna, hvála drâgom bögu, neg sam bíla prijepódne $>$ do mälo prije na röđendanu, pa sam se nàpūhala (sic) mälo. - Sëksala sam se cjélu nôč. Tô sam trëbala rëč.

4. Tî si na počétku rekla, ödi tî, pa ču jâ móžda dôč. Önda je bílo 'néču', al mu nisi tjëla ïzravno rëčc, jëbo te, néču, ne zànīma me, náči, kategórički òdbïjam, nécu. Mälo jèsi tî tû, mälo bi ti ì jā tô zámjerila je si ga tëntala, rëalno. Nisi mu rèkla, kad je ôn rëko 'jâ idèm', 'okêj, a jes tî svjëstan da jâ ne ràzmātram òdlazak iz òvē države nïgdje, $p a$, .. në znam, dok mi nè dōđu gôvna do gr̈la. Nísi mu tô täk rèkla. Neg si rèkla, äjd ödi tî za počétak, pa čemo viiit ${ }^{37}$, ak se mëni tû stvâri ne pòprave - a nísu ti se bäš pòpravile -, önda ču jâ dôč.

5. A.: A òvāj je napisō Jéhovin > rèlīgijsko opredjeljénje Jéhovin svjèdok. — B.: Säd, kad mu dôđu, pa če önda bìt 'Štä, kô, štä öčte vîtû?' - C.: A dòbro, níje sïgurno adrèsu stävio. — B.: Pa käko në, kad môraš imat òvaj .. kö kod prìjāvnice. Bêbo, nï̌ta: tî ònū knjïgu ak nís bäcila òd njīh (tj. od Jehovinih svjedoka), pošàlji mu tämo .. na Vükovarsku. Pošto smo käo na ìnternetu vïdjeli, jèl, da ste vî tô, vâmo-tämo...

6. Tráźili su àgente na əo telefónima. Zä öpče informácije. Znâči, doslòvcē, u nätječaju je písalo, vî ste, në znam, əəə > znáte se slúžiti internetom, $i$ tô je svë što ti trëba. Trëaš bït, okêj, ljübazan ì ì nê znam, onäk, .. nörmalno nëkako òbavit räzgovor: čòvjek če te nàzvat i pitat ' $\hat{E}$, kàkvā je temperatúra dànas $u$ Londónu?', tî̌s mu iz̀gūglat $i$, në znam, i rëčeš mu. Náči, möžeš > .. nàzvače te nëko, pitače, kòjē je râdno vrjéme nëke bànkē, në znam gdjë.

\footnotetext{
37 O gubljenju suglasnika među samoglasnicima v. Kapović 2011: 23.
} 
Upravni govor može sadržavati i često sadrži elemente dramatizacije, tj. u upravnom se govoru original, kao što je rečeno, obično inscenira u većem ili manjem stupnju. Za variranje količine elemenata dramatizacije, odnosno stupnja inscenacije usp. 1., 7. i 11. primjer, gdje je stupanj inscenacije relativno velik, s 4., 13. i 38. primjerom, gdje je stupanj inscenacije relativno malen ili nulti. S funkcijom je inscenacije originala povezana i činjenica da upravni govor prenosi više elemenata ovojnice nego bilo koji drugi tip prepričavanja diskursa. Doduše, količina elemenata ovojnice koji se prenose u prijekaz u upravnom govoru, nije zadana, nego može varirati od govornika do govornika i od slučaja do slučaja (usp. 1. primjer). Od elemenata se ovojnice u upravni govor nužno prenosi orijentacija, odnosno deiksa. Naime, ne postoji pravilo po kojem bi se bilo koja vrsta originalne deikse (lična, vremenska, prostorna, socijalna itd.) prilagođavala situaciji prijekaza, pa se deiksa prijekaza može smatrati vjernom originalnoj onoliko koliko ju je točno uspio ili htio prenijeti prekazivač. Drugim riječima, u prijekazu u upravnom govoru kao polazište orijentacije služe isključivo koordinate originala, iako su moguća određena odstupanja od originala, koja se mogu shvatiti samo kao netočan prijenos originala, a ne kao promjena deiktičke perspektive ${ }^{38}$. Doduše, iako postotak prenesenih elemenata ovojnice i vjernost originalnoj ovojnici nisu isto, te je parametre vjerojatno nemoguće dosljedno razlikovati. Uz to što se obavezno prenosi iz originala u prijekaz, za orijentaciju se može pretpostaviti da se u pravilu prenosi i najvjernije. Međutim, analizirana građa to niti potvrđuje niti osporava jer mi u velikoj većini slučajeva originali nisu poznati. Ipak, u slučaju socijalne deikse nije nužno poznavati original da bi se utvrdio odnos prema originalu. Tako su mi poznati slučajevi kad su prekazivači u upravnom govoru riječi originalnih govornika navodili kao da im se oni obraćaju sa »ti«, iako mi je poznato da im se oni obraćaju sa »vi«. Kad se govori o deiksi valja imati u vidu i činjenicu da glagolsko vrijeme nije isključivo deiktička kategorija nego da može imati i razna druga značenja. Tako je u osječkom upravnom govoru moguće pretpostaviti varijacije vremena (historijski prezent/perfekt, prezent u futurskom značenju/futur I., krnji perfekt/ historijski prezent/puni perfekt, svršeni prezent/futur II.) koje ne bi bile primarno deiktičke, a u govorima s više glagolskih vremena moguće je pretpostaviti još više takvih varijacija. Isto, ali u manjoj mjeri, sigurno vrijedi i za neke druge deiktike, kao što su razne pridjevske i priložne pokazne zamjenice.

Manje se obavezno i manje vjerno od orijentacije u prijekaz upravnoga govora prenosi drugi dio originalne ovojnice: način priopćaja. Tipična su obilježja načina priopćaja ekspresivno-dijaloški elementi, jezik, dijalektalne, sociolin-

38 Tvrdnja proizlazi iz definicije upravnoga govora, jer ako se deiktička perspektiva promijeni, onda više nije riječ o upravnom govoru, nego o nekom drugom tipu prepričavanja diskursa. 
gvističke i stilske osobitosti, govorne vrednote te ostale pojave koje prate govor. Ekspresivno-dijaloškim se elementima smatraju pojave kao vokativ, imperativ, optativ (neke upotrebe), razni tipovi elipse glagola, krnji perfekt, razni usklici, njima slični idiomatski izrazi i općenito mnoge usklične rečenice, upitni izrazi kao zar ne?, retoričko pitanje, prezentativi ëvo, ëto, ëno, etički dativ, ekspresivna ponavljanja, a ovamo se mogu dodati i neki konektori, npr. pa, $i$, ali. ${ }^{39}$ Svi oni mogu stajati u prijekazu upravnoga govora, i nema pravila koje bi ih $\mathrm{u}$ tom ograničavalo. Koliko se vjerno prenose, ovdje nije moglo biti istraženo, ali se sam po sebi nameće zaključak da ih prekazivači mogu i oduzimati i dodavati $\mathrm{u}$ odnosu na originalno stanje, ovisno o njihovoj sklonosti $\mathrm{k}$ dramatizaciji. Zanimljivo je kako se u upravnom govoru postupa u slučaju kad jezik originala nije identičan jeziku govorne situacije prijekaza. Prema Evansu (2013: 73) $\mathrm{u}$ engleskom i mnogim drugim jezicima uobičajeno je da se original pri upravnom govoru prevodi na jezik koji se upotrebljava u situaciji u koju je uklopljen prijekaz, ali to ne vrijedi općenito, pa tako u mnogim aboridžinskim jezicima prekazivač zadržava jezik originala čak i kad može pretpostaviti da adresat taj jezik ne razumije. U analiziranoj građi nije bilo slučajeva nepoklapanja jezika govorne situacije prijekaza i jezika originala, ali na temelju vlastitoga iskustva, ponajprije s njemačkim jezikom, mogu zaključiti sljedeće. U osječkom se upravnom govoru, ako adresati ne razumiju jezik originala, original obično prevodi. Iznimke su uglavnom samo više ili manje općepoznati kraći izrazi. Slična je situacija i kad je jezik originala adresatu poznat. U tom se slučaju duži odsječci govora također obično prevode, iako ne uvijek, a na izvornom se jeziku iz različitih razloga mogu zadržati neki kraći dijelovi. Naravno, može se pretpostaviti da situacija ne mora biti ista u slučaju kad je prekazivaču materinji jezik jezik originala i kad mu je materinji jezik jezik prijekaza, ali u ovom se radu fokusiram samo na drugu mogućnost. S dijalektima je situacija nešto drukčija nego s jezicima. I u ovom se slučaju ima u vidu samo situacija kad dijalekt/ govor originala prekazivaču nije materinji. Hoće li prekazivač u takvoj situaciji prenositi dijalektalne osobitosti u vlastiti govor ili ne, uvelike ovisi o sklonostima prekazivača, ali i o funkciji prepričavanja. Naime, prenošenje tuđih dijalektalnih osobina u prijekaz za neke prekazivače može biti barem djelomično automatizirano, ali, bez obzira na to, ono obično služi da istakne neke dojmljive osobine originalnoga govornika. Prekazivač te osobine smatra dojmljivima iz raznih razloga, npr. zato što su mu komične ili iritantne. Pri tom prekazivač, naravno, dijalektalne osobine ne prenosi sasvim točno i nerijetko ih prenaglašava. U analiziranoj se građi nalazi nekoliko prijekaza govora jedne osobe čija akcentuacija ima neke staroštokavske elemente (ovdje je zovem Jasna),

39 O ovim elementima usp. Падучева 2010: 341 sq. і Renzi, Salvi, Cardinaletti 2008: 449 sqq. 
a također njezin originalni govor. U 1. primjeru Jasnin govor prepričavaju prekazivačica A., koja u prijekaz ne unosi nenovoštokavsku prozodiju, i prekazivač B., koji je u prijekaz unosi vrlo umjereno, a u 7. primjeru Jasnin govor prepričava prekazivačica (A.), u čijem se prijekazu nenovoštokavski naglasci nalaze češće nego kod same Jasne, između ostaloga i na mjestima na kojima se oni kod nje ne bi mogli pojaviti (usp. sa 9. i 23. primjerom, u kojima se nalazi izvorni Jasnin govor).

7. A.: A kâžem ti kad je príčala kad je u bólnici òstala: jēbô te, štä je òna tîm döktorima... Svë poslágala, Äna, i vôče i svë na ormárič, .. i sèstra joj rèkla da nè smije... — B.: Nè smije tô. — A.: ...jôj... Àjde sämo, kaže, da jâ... — B.: Sämo vòda... - A.: Ajje sämo da jâ vïdim da tô nëko mäkne. Kâže òna, ali môramo zbog vizite. - Köje vizite, köje? - Pa döktorove. - Jâ ču se s döktorom obračùnat, a vî tô da niste pïpnuli. Äko... > Jâ ne mögu, kâže, jâ stálno daəo se dǐžem, .. štápom? - Kâže .. òna, ovaj, .. ali môrate, göspođo. - Äko döktor kâže da môra, môra. Ako döktor kâže da môra, jā ču to svë poküpit u kësu i jâ idèm küči. (...) Òna käže, jeste imali stólicu?: jēbö te kad je òna pöčela prîču. Stòlicu? Pa nísam ni kâvu jütros popilla: dok sam se dìgla, pa üzela sämo törbu na räme, pa vâmo kod döktorice, pa ùputnicu, pa tämo, pa u bôlnicu (prekazivačica nabrajajući udara rukom po stolu), pa kr̂v vädi vâmo, tämo... Dï, kâže, .. od čègā stòlicu? — C.: (kroz smijeh) Nísam ìmala, nísam imala vrëmena da öpče da sjëdnem, a kàkà stòlica?, čövječe.

Dok se u prethodnom primjeru dijalektalne osobine u prijekaz unose barem djelomično radi pojačavanja komike, u sljedećem se primjeru one unose u prijekaz vjerojatno kao pojava koja prekazivačicu dodatno iritira.

8. I önda, kak su nam .. əə o- ònō mälo po mälo povláčili spïse sëbi u Zágreb, ōvāj .. önda su stálno bíli na telefónu, znaš, pa pàljba: 'pa käj ste òvō?, a käk ste òvō? ${ }^{40}$ : a jèbō te vǐse, ùzmi pa čitājj.

Osim dijalektalnih osobina te sociolingvističkih i stilskih osobina, o kojima u analiziranoj građi nema podataka, pri upravnom se govoru iz originala mogu prenositi i neke druge osobitosti govora, kao što su govorne mane ili, kao u 9. primjeru, tepanje. Modifikacija se govora kao u prethodnom primjeru, naravno, ne može smatrati prenošenjem osobina originala, nego eventualno njihovim karikiranjem.

9. I jâ öpe lëgnem .. i jâ zàdrēmam, käd, pôl dvánaes pròšlo, ëvo môg Märina: 'Mámá, jel pâvašs?'. Ja käem, pa dä, pòmalo, jâ na ráte.

40 Informantica se u prijekazu koristi modifikacijom govora koju bi u nedostatku stručnih termina bilo najjednostavnije nazvati kreveljenjem. 
10. I Zlätko njëmu, kak je bïo prèhlađen, níje se mögo dèrat, znâš, i Zlätko ovak kao: tî pi mrtav dà mene. ${ }^{41}$ (...) — Kö pïčkica nëka s ònīm glâsom pròmūklim. (...) - (...) A òvāj njëmu käže mrtvo-ládno: 'Štà ti je s glávōm?'.

U upravni se govor prenose i govorne vrednote. I njihovo prenošenje ovisi o sklonostima prekazivača, o funkciji prijekaza, a također o funkciji i vrsti samih govornih vrednota. Za fonacijske govorne vrednote usp. oblik mámá (prvo je dugo naglašeno $a$ višega tona, a drugo nižega) i tih tanak glas u prethodnom primjeru te tihi govor i coktanje jezikom u sljedećem. Međutim, ne prenose se u upravni govor samo fonacijske govorne vrednote (tempo, dinamika, intonacija, stanke i sl.), nego također mimika i geste (usp. 20. primjer), ali i neverbalne obavijesti koje izlaze iz okvira govornih vrednota, kao što su oponašanje hoda u 1., ljuljanje i otvaranje patent-zatvarača u 11. te udaranje rukom po zidu u 52. primjeru, a možda i udaranje rukom po stolu u 7. primjeru.

11. (...) Në, òna òno... Oväk glëda-glëda-glëda-glëda - svì se ràzišsli, .. a Míra sjèdī, Míru níje ni skúžila, a Míra .. ònō, šútī, dòbro je. E! ${ }^{42}$.. Jâ bi, kâže, böbi pikant, ònāj, käže, sa kikirïkijem, znâšs:.. smöki s kikirïkijem, nëšto... Reko: .. slüšaj, reko, Marinëla je .. > jâ nêmam kod sebe ni lïpe, reko, kad dôđe Marinëla, pa čemo vïit nëšto, väm-täm. $C$ (coktanje), .. ahâ, dòbro-dòbro. Ljûlja se oväk, i öde u sálu, i ništa... Pròšlo jèno sëam-ösam minútā: .. dòlazi, ìmā sad ònū tòrbicu, nâš, .. tòrbicu preko rämena nëku mâlu, di joj je mòbitel, nâš òno käo... Dôđe dò mene: êj, Läslo! Reko, mölim. Oväk räjf òtvāra (prekazivač sam otkopčava neki patent-zatvarač)... Ê Äj donèste mi s kikirikijem. Pïčka ti mâterina, čöeče, dëset kúnā papirnato, kùiš òno, a mälo prïje da joj jâ kûpim kao ònō vâmo-täm.

Prijekaz se u upravnom govoru markira glagolima govorenja i nekim drugim glagolima, naznačavanjem originalnih adresanata i adresata i nekim manje specifičnim markerima. Naziv je markeri prijekaza točniji nego što bi bio naziv uvodni elementi, zato što se oni ne nalaze samo na početku prijekaza, nego se mogu i više puta ponavljati unutar prijekaza, a mogu biti i njegov neodvojiv dio. Od oblika glagola govorenja prijekaz pri upravnom govoru najčešće markiraju sljedeća tri oblika: kâže, kâžem (relativno često su reducirani kao kä(ž) $e, k \ddot{a}(\check{z} e) m, k a(\check{z}) e, k a(\check{z})$ em itd.) i nenaglašeni ${ }^{43}$ oblik reko (rijetko se reducira u $k o$ ). Oblici su kâže i kâžem gotovo uvijek u historijskom prezentu, što ukazuje na to da su za upravni govor karakteristični upravo narativni konteksti te da je

${ }^{41}$ Tihim tankim glasom. Glasovi $p$ i $\partial$ umjesto $s$ i $z$ vjerojatno služe da bi na neki način dočarali govor prehlađene osobe začepljena nosa.

42 Prekazivač pri navođenju originalne adresantice u cijelom primjeru govori tiho (polušaptom), kako je vjerojatno i ona govorila da je drugi ne čuju.

${ }_{43}$ Oblik je sasvim rijetko naglašen kao rëko, ponajprije ako je i pred njim i iza njega stanka. 
sam upravni govor svojevrstan »produžetak « pripovjednoga režima interpretacije. Na narativnost konteksta karakterističnih za upravni govor ukazuje i historijski prezent glagola kojima se opisuje neverbalno ponašanje originalnih sudionika komunikacije (usp. 1., 11. i 20. primjer). Klauze s oblikom kâže češće su komunikativno neraščlanjene nego raščlanjene, odnosno većinom se ne dijele na temu i remu, nego su potpuno u remi. ${ }^{44}$ Komunikativna se neraščlanjenost formalno očituje tako da subjekt, ako je izrečen (a vrlo često je neizrečen), stoji iza glagola, a ne ispred njega (usp. 7., 20., 55., 66. i 70. primjer). Ova je pojava naizgled sasvim trivijalna: kad postoje za to razlozi, govornik se tematizira, tj. izdvaja iz procesa označena predikatom, a u suprotnom se uklapa u proces. Ipak, zanimljivo je da, na primjer, u mnogim čakavskim govorima takav red riječi uz odgovarajući oblik govöri vrijedi samo za imenice, dok je lična zamjenica trećega lica gotovo uvijek pred tim oblikom, a iza njega iznimno. ${ }^{45}$ Doduše, u analiziranoj građi ima i nekoliko primjera u kojima subjekt izražen ličnom zamjenicom stoji pred glagolom. U građi su to samo primjeri kao ôn/òvāj mëni/njëmu kâže. Oni se pojavljuju u dijela informanata, dok se u drugih informanata nalaze primjeri kao kâže ôn mëni. Teško je reći u kojoj je mjeri red riječi tipa ôn mëni kâže osobitost govora pojedinih informanata, a u kojoj je mjeri uvjetovan kontekstom, ali je sigurno da on ovisi o oba spomenuta faktora. Za takav, rjeđi red riječi usp. primjere 10. i 12.-14. U slučaju je osječkoga oblika kâžem, uz koji ne može doći imenički subjekt, lična zamjenica jâ u većini primjera pred glagolom. Svi primjeri sa zamjenicom jâ iza glagola potječu od jedne informantice. Uz oblik kâžem u velikoj većini slučajeva dolazi lična zamjenica u nominativu, a nema je rijetko, kao u 7. i 24. primjeru. Objekt je u dativu (adresat) uz kâžem relativno rijedak (usp. 15., 20. i 56. primjer). S druge strane, uz oblik reko, koji se također upotrebljava za prvo lice jednine, u pravilu nema ni subjekta ni dativnoga objekta (subjekt uz reko ipak je zabilježen nekoliko puta - usp. 21. i 25. primjer). Reko je prežitak aorista, a upotrebljava se slično kao historijski prezent jâ kâžem. Između tih dvaju markera postoji jedna stilska/sociolingvistička i barem jedna funkcionalna razlika. Stilska i sociolingvistička je razlika u tom što je reko regionalizam i ima odgovarajuće konotacije, pa će ga manje upotrebljavati osobe kojima je stalo da te konotacije izbjegnu, odnosno oblik će se reko manje upotrebljavati u slučajevima kad je poželjno izbjeći takve konotacije. Međutim, iz analizirane se građe vidi da postoje osobe koje preferiraju jedan ili drugi marker neovisno o sociolingvističkim i stilskim faktorima. Oblik reko prilično često upotrebljavaju i $\S 2138$.

44 O komunikativnoj neraščlanjenosti rečenice v. Падучева 2015 pod 4 і Шведова 1980:

45 To odgovorno tvrdim za ugljanske govore, kojima se bavim. 
mlađi i stariji informanti. To svakako vrijedi za informante između 30 i 76 godina, dok govor ostalih informanata nije (dovoljno) zastupljen. Za funkciju bi se oblika reko i historijskoga prezenta jâ kâžem moglo reći da je većinom ista. Ipak, oblik reko neće stajati, ili barem nije uobičajen, u slučajevima kad se navodi adresat (?reko jâ njëmu), a ni u slučajevima u kojima subjekt valja istaknuti kao temu, fokus kontrasta i sl. Osim toga, reko se upotrebljava znatno češće nego jâ kâžem kad govornik ne prenosi vlastiti govor, nego vlastite misli, iako se u toj funkciji mogu upotrijebiti oba spomenuta markera kao i neki drugi.

12. (...) i jâ kâžem 'znáte štä: krêče àtak, jâ se povlāčim', i ôn mëni kâže 'vïdim: blägo väma, vî bär möžete', znâšs.

13. (...) I okêj, ôn mëni kâže 'tî u tôm svèmu önda glëdaš nà sebe': dâ, glëdam nà sebe ōvaj .. käo što tî glëdaš nà sebe.

14. I jâ dôđem kòd njega po kòvērtu, i ôn mëni kâže, ë, .. dànas dòlazi Ànita, tâ kao šèfica administrácije, pa ču jâ ovaj vïdit s njôm svë pa ču te obavjéstit. jèbi ga, reko, Slävene, zakàsnili ste: jâ döbila. Ü jèbēm ti, kâže ôn, štà ču jâ säd.

15. Jâ tô izmjéšō, čöeče. A óna, tô ti, İvane, nè bi löše bílo, .. kae, ùzêt fino .. to mêso, .. málkoc u bräšno, málkoc sämo pròpržit, kâže, na ûlju, .. i önda, kâe, tö kad vî öčte.

16. Mëne je nà tāj drügi räzgovor kad sam išla na še- > u šečerànu, vòzila nëka tàksistkinja .. i käo əə säd òna mëni 'kàko ste mi vî dànas', hehe. Ijâ ònō.. näpeto. - Zäšto? - I säd jâ njôj kâžem, pä, ïdem kao na räzgovor. - Achâa dòbrodòbro.

17. Zlätko mi je rëko .. jùčē käo, jel tî plànīraš îč na Àdvent u Zágreb; käžem ja, në: nísam planírala; kao ëvo, prïjatelj mu je jávio da su döbili stánje priprávnosti čètiri, a pêt je teroristički nâpad.

18. I säd, kad je ôn òšō, kâžem jâ, štä si slägo čovjeka? - Ä, jèbi ga, ionäk sam pòpravio, níje säd tô nèšto, tô ste vî, vî nëš ste, ònō .. vâmo-tämo. - Kâžem jâ, a za kádu? - Ë, sjëtio sam se, al níje säd jöš vrjéme da mu tô kâžem.

19. (...) Kúpili kökoše nëke, znâšs, vâmo-tämo, i säd bìo dùbok > dùbok snjêg. Säd jâ, kâže, glëdam, glëdam, štä s kökoš (... nerazgovijetno), a kökoš, kaže, zàpala u snjégu. —Dvê-trî kökoške pòbjegle .. u snjêg. —Pòbjegle. I säd u snjégu i zàpale, čöeče bòžjī. - A òna, kaže, mórala prìō lòpatom snjêg... - Pa, léga, käk da dôđe dò njīh, pa lòpatom vâmo-tämo da òčisti snjêg da izìđu vân. Kaem, pa jèbō ga tî, pa tô s ti, reko, ljëtne kökoši, čöeče. Kâže, käk mìsliš? Pa säd zîmske móraju imat skïje, reko, pï̌ka mu mäterna, da ti ne zàpadnu u snjégu.

20. Jâ kâžem Dâliji, pa štä je ôn napísō tô? Kâže ona, pa-ováko pokàzuje -, pa jel vî znáte da ôn níje nörmalan? 
21. I nazòvē ti òna mëne vídeopózivom i òkreče tâj, znâš, mòbitel i... Jā reko, göre, Mâjo, göre vam je küčica.

22. A në znam. Dòšo je dölje bio .. na rúčak i kâže, tìtrā mu svë slìka nëšt. Jā rëko 'käk ti tìtrā??': në znam, prèklāpa mi se.

23. (...) I jâ kâžem (tj. sama sebi), reko, rûčka ïmam, ìdem jâ säd br̈zo vïdit $u$ rècept štä $m i>$ jel mi nèšto fâli.

24. I Ìvan kâže, äj kúpi mi örāha mälo. Četrës kúnā òrasi. Tô jöš nije ni püno, znäli su bït i pedespêt. Jèlda jèdno vrjéme? —Dä. — Äj, reko, ïdem mu ùzèt za žèlju, jöš käžem (...)

25. Nači, üsmeni > pïsmeni je bïo üjutro u ösam, üsmeni je bïo vëč u pôl jèdan. Òna i je dòšla u pódne, .. i jâ sam dòšla u pódne, jer sam > nísam znäla oču znät nâč tû > tâj kabinêt, .. i reko, äjd idèm rànije, pā nišsta: št ä, sjěšč tämo i zújiču mälo.

Perfekt glagola rëč(i) kao marker prijekaza pri upravnom govoru upotrebljava se u govornom režimu, tj. kontekstima u kojima historijski prezent, odnosno pripovjedni režim interpretacije, nije moguć ${ }^{46}$ ili se ne preferira. On je s tim u skladu uobičajen uz priložne oznake načina, uzroka i vremena u upitnim i zavisnim rečenicama te u njima formalno sličnim konstrukcijama, uz negaciju i u nekim drugim kontekstima. U ovom slučaju subjekt, bila to imenica ili lična zamjenica u kojem god licu, obično stoji pred glagolom. Drugim riječima, prijekazi markirani perfektom od rëčc(i) komunikativno su raščlanjeni, odnosno subjekt je jasno izdvojen iz procesa. Smatram da je to u skladu s režimom interpretacije. Naime, u pripovjednom je režimu naglasak na nizanju događaja, a subjekt, tj. entitet, se uklapa u događaj tako da se rečenica ne raščlanjuje (pojednostavnjeno rečeno, ne pita se što subjekt radi, nego što se događa). U govornom je pak režimu uobičajeno da se na sceni prvo pojavljuje subjekt, a da se potom o njemu nešto kaže (pojednostavnjeno rečeno, obično se pita što subjekt radi, a rjeđe što se događa). Uz sljedeće primjere za perfekt glagola rëč (i) usp. također 4. i 71. primjer.

26. (...) A zàtō što ôn rëko, tô nâs ne zànīma, tô je mòja sèstra prïje čìtala, .. znâš, .. Màrija. I säd òna, 'jel süprug kòd kuče?', kúžǐšs?

27. Prì̄o je rëko, nêče îč, önda je rëko, äjd ïdem, kaže, mälo. (...) Prìō je rëko, öče-nêče, znâš, jer je Mârko rëko käo, ak öš, dóđi, ako nêš nè mōraš (...)

28. (...) E önda mi je jèdna žèna rèkla - u biti nâjprije je bíla òvā pätronažna -: üjutro kad se ùstaneš, prirédi si näveče köricu krüha i nèmōj se ùstajat,...

46 Postoje konteksti koji u pravilu onemogućuju pripovjedni režim interpretacije, kao pitanje, oznaka trajanja itd., usp. Падучева 2010: 14 sqq. Narativna interpretacija nije moguća ni u mnogim zavisnim rečenicama. 
pòjedi tû köricu, mälo odlèži .. jöš u krèvetu, zažmíri i önda se... Jôj, próbala sam i tô, bílo mi to prìo smjéšno, al kad stvárno vǐše nísam mògla (...)

29. Jâ sam srëla mòju ovaj döktoricu, jèl, ginekològinju u grádu... .. Sämo me je pògledala i rèkla: käd s tî zàdnjī pût bíla kòd mene? Pa poslje póroda. Pa krâsno, kâže.

30. A da si rëkao, Mìslave, .. Nâdo, oš čìps? 'Möže.' I gòtovo, znâš ònō. Oväk, jâ joj näbrojo pâr stva-... Jebö te, je se zbúnila, nâš ònō. Òna bi käo i òvō $i$ òvō $i$ òvō, svë käo.

31. Käk je Pávlovička rèkla: Sönja, òvō je tvòja gödina. Ajjde, reko, .. da vïdimo.

32. Štä jâ znâm: mòžda se uöpče nè snāđem. Jâ, jâ s računovòdstvom nëam nïkakvo iskústvo, iako mi je žèna rèkla, tô je svë što > svë se tô dâ naùčit: .. náči, ni ekonomïsti ne ì̀āađu s fâksa pa da znäju rádit, svì ùčè, ōvāj .. svë je stvâr kòlkō höčeš i kòlkō imāǎš klïkēra, i ònō... ${ }^{47}$

U analiziranoj je građi sporadično zabilježen i glagol rëč u drugim oblicima kao marker prijekaza, a sporadično su zabilježeni i drugi glagoli koji markiraju upravni govor kao govòrit, príčat, (dogovòrit se), víkat, napisat, bezlično písat, pitat, (is)komentírat, bit, pòslat i neki drugi glagolski te djelomično ili potpuno neglagolski markeri. Uz sljedeće primjere usp. i 3., 4., 5., 6., 8., 10., 47., 77. i 174. primjer.

33. I önda če dôč tämo i rëčć òvā djèca mi òpēt nísu dála.

34. Misim .. ònō, u pâr návrāta je znäo rëč, ònō, jâ lëgnem sâm, ìsto, ònō, nè spāvam...

35. Tolikō ga sïluju, da ôn jëdnostavno .. i da pétpūt kâž $e^{48}$... Nëki dân je rëko nëšs, šta sam jâ... — 'Prìprēmam rúčak.' - 'Prìprēmam rúčak', i öa sam vikala 'nêma zajebàncije', da täk nëko cuüje: nëš je > ôn je iskomentírō käo djèca su me käo .. djèca su me käo > nè puste me käo, môram tû nëšt, a jâ vîčem 'nêma zajebàncije'.

36. I önda smo Beäta i jâ komentírale käo ònō, dê, Läna, tëbe čemo bäš òdbit, ònō.

37. I òna je njëmu cjélo vrjéme govòrila, kad izāđete vân, nêčete znät štà ste vïdjeli, štä niste, nêčete zàpāmtit. Znáčīi, göre ìmāte...

38. Tô Zlätkova Läna pòslala òvāj, käo, oče òvā čâsna säd u pàkao?

47 Ovo je granični slučaj, koji se može shvatiti i kao polunavođenje (v. pod 7). Drugo se lice može shvatiti kao opće drugo lice.

${ }_{48} \mathrm{Tj}$. ne može odbiti ljude koji ga zovu da se s njima druži. 
39. Mëne jèdīno tô jèbē säd što me svï tïskaju: kä če bït svätovi?, kä če bìt svätovi?, i önda käo: znâš da bi tî trëala ròdit, da ti küca bïološki sât? Štä te bòlī kürac: küca môj, nè kuca tvôj, jëbo te.

40. A njègov komèntār je: pa ì jā sam tô rádio.

41. I önda ôn > njëgov je záključak svègā: jâ sjèdīm kòd kuče i tëbe čěkam da tî dôđě́s.

42. Mëni je nâjbolji Zlätko kad kâže, kad jâ pöčnem brûndat 'jèbēm ti küču, jèbēm ti ùkučane: nìko nï̌st', önda ôn kä-, jâ ču u nèdjelju ùsisat. Dôđe nèdjelja, a ôn: jôj, pa štä me nís pòdsjetila?

43. Täta oväk glëda ù mene 'Kö je tô?', jâ oväk 'Mòja šèfica, šúti.'

44. Ali .. nâš ònō: dôđe nëko kúpit kârtu, ha onäk, 'opròstite, môrate čëkat da aviōn öde.'

Prijekaz u upravnom govoru ne moraju markirati glagoli govorenja i njima bliski glagoli. Štoviše, mogući su i prijekazi bez ikakva neposredna markera. U tom se slučaju radi kratkoće može govoriti i o nultom markeru ili nuli. Ipak, i pri nultom markeru adresatu mora biti jasno da je riječ o prijekazu. To se postiže s jedne strane pomoću konteksta, koji i bez glagola govorenja može adresata pripremiti na prijekaz, a s druge strane pomoću osobitosti samoga prijekaza: njegova verbalnoga sadržaja, govornih vrednota i neverbalnih osobina. Ni smjena govornika originala unutar jednoga prijekaza ne mora se posebno naznačavati ako je uočljiva iz teksta, govornih vrednota i drugih neverbalnih elemenata. Neposrednoga markera vrlo često nema u nekim slučajevima nereferentnosti originala ili originalnoga govornika upravo zbog nereferentnosti, tj. zato što je riječ o slučajevima u kojima se ne može tvrditi da je netko konkretan nešto rekao. Takvi su slučajevi nereferentnost originala pri parodiji neke situacije (usp. 45. i 7. primjer, a i nešto drukčiji 49. primjer), nereferentnost originalnoga govornika zbog iterativnosti situacije (original se u osnovi ponavlja, ali govornici ne moraju, iako mogu, biti svaki put isti, usp. 46. i 48. primjer) i imaginarno obraćanje stvarnoj osobi ${ }^{49}$ (usp. 8., 22. i 47. primjer). Naravno, markera ne mora biti ni u raznim drugim slučajevima.

45. A.: Kâže Jäsna, 'Mârko, ìmāmo no-? Ïmamo, ïmamo növaca. İdemo kúpit > kúpiti nëšto. 'Mârko kâže, àjde, tî izabèri pòklon. Žèni ïzabrala čëtke za kösu i ïzabrala njëmu dezodòrans i nëš za brìjānje. 'Nëka ìmā, kaže, Mârko, tô je jèdna üspomena ljêpa. - B.: Vjëčna üspomena, në ljêpa. - C.: Pästa za zûbe - vjëčna üspomena. Hahahahahaha. Tâ smo kúpili: ëto, Zirodënt, nek imā vjëčnu üspomenu i gòtovo. — A.: 'Döšso: jâ naprävila vînski gülaš.' (...)

49 To je svojevrstan prekazivačev komentar na tuđi iskaz ili čin koji je prepričao. Ovu pojavu treba terminološki razlikovati od smjene govornika, iako te dvije pojave u konkretnim primjerima nije uvijek moguće razgraničiti (usp. 13. primjer). 
46. A.: Jöš prïje kad je dòlazio: ònō müvice pô tôrbe. B.: Önda vädi rêžje: .. dê vïdi jel òvō plâčeno. — (...) A rècimo, .. sjèdǐš pored njëga, öde ti nôs u pïcku. (...) Čika Mirko, izvòlte pîvo tû. ${ }^{50}$ - Ahâ, dòbro, möže, möže. Onda vädi, onda odjèdnōm bü - öde pîvo u pïčku mäterinu: na stòlu se prèvrne. Jôj! 'Pàrdōn.' Ájde.

47. Jâ ödem, .. nit me prègleda nit ništa: .. môrate ï̌ na operáciju. Äj dòbro, jâ mìslim, kad dôđem u bólnicu, prègledače me. Nǐ̌t. Jâ išla na operáciju bez prégleda bez ǐčega. U bíti na propuhívanje, jë, .. al me je rëzo. Da bi ôn pöslje tôg rëko, vî môrate pönovo: nakon dvâ mjësca operácija. Mölim? Ma čövječe, nêma šänse. I pöslje tôg jöš na ùmjetnu oplódnju. Ma dâj tî mëni rëc kòjī jâ ìmām pròblēm, zäšt jâ idēm na ùmjetnu oplódnju. Néam nïkaki pròblēm, štä č jâ säd bèz veze ònō?

48. Òne mëni održávaju svë što trëba. 'Nèmōjte vî mî čemo, nèmōjte vî mî čemo.', preko púta mëne, evo tàkō. I kad smo krëčili, jâ nísam dòlazla küč četrìaes dánā: 'Nèmōj dòlazit, mäma, dok svë nè bude gòtovo. ', kad smo stân sređivali.

49. (...) A Milénko kòntā. Käk s tî ònō zòvēšs? Kaže, Náda. A jel bi tî koláčā mòžda? Käo bî, da. I Milénko, äjd, èvo ti. Kad òna ovàkō, léga: ràšîri, léga, prèd njū i ùdri. Milénko joj prîča... Ma säm tî prîčaj, rôđo. — A Milénko svë: očeš jöš jèdan, očeš jöš jèdan. — 'Pä möže.'

50. Jùčē sam bíla kod döktora: kâže, trî kìle ste se üdebljali. Kad jâ nè mogu mänje. A ôn se smíje, käko nè možete? Pa nè mogu.

$\mathrm{U}$ prijekazima bez glagola govorenja kao neposredni markeri mogu funkcionirati oznake adresanta i adresata ili samo oznaka adresanta. Uz sljedeće primjere usp. i 15. i 42. primjer.

51. İ ovaj, dôđemo na blàgājnu, i òvā kâže ovaj käo: jeste vî bölesni? Jâ kâžem, nê. Jôj, kaže, svä ste mi nàtekla .. > otèčena. Svä ste otèčena, znâšs. Jôj jâ Ani: jesi vïdila, .. jesi vïdila štä mi rèkla òvā, .. da sam svä na-?

52. (...) I ôn ödma üšō i ödma slïku srüšio. A Mârko polúdio. — 'Šta je to?, lampèrija?' Dü slïka döle. - Ôn dòšo: â, a lampèriju ste vî tô tû (prekazivačica udara rukom po zidu), â. Jëbō te. — Slikka bû döle. — A Mârko nà njega: pa Mîrko, pa pïčka mu mäterina, prì̄ pût u küči.

Postoji još jedan nespecifičan marker prijekaza koji donekle zamjenjuje glagole govorenja. To je čestica käo. Ona je nespecifičan marker prijekaza zato što uz funkciju markera prijekaza ima i neke druge funkcije izvan prepričavanja diskursa. Za nju bi se moglo reći da je s obzirom na svoju funkciju u pre-

\footnotetext{
${ }^{50}$ Adresant originala može biti bilo tko.
} 
pričavanju diskursa na pola puta između oznaka približnosti i skraćivanja originalnoga diskursa, koje se obrađuju pod 8, i markera prijekaza kao što su glagoli govorenja. Zanimljivo je da u toj funkciji u osječkom govoru dolazi upravo oblik käo, a ne oblik kö/ko. Käo se može i ne mora kombinirati s glagolima govorenja i srodnim glagolima. Uz sljedeće primjere usp. i 1., 5., 27., 49. i 51. primjer.

53. Poslje operácije tû u Ösjeku .. döktor kâže, bïče svë u rédu, bïče svë u rédu; dòšla jâ za mjësec dánā: väši jajnici öpče nísu ovaj .. prólazni, i tô käo nêma šănse... Äj dòbro.

54. Dâlija je napísala 'ìnteresi - muškárci i žène'; .. pïčka joj mäterina. — Ma òna je tô slûčajno: käo 'zanímaju me: .. muškárci i žène'.

55. I käe mëni Vüčko: aj vîcu jâ sa mämom, kâže, imà ti òna kao nëki šväpski gröb .. kao tû ìmā pünomoč käo iz nëkih Švábā iz Njèmačke, jèl, vâmo-tämo (...)

56. A ljêpo, jâ im kâžem: glëajte, göspođo, ovàkō: mòja sùpruga níje zainteresîrana, .. reko, üpravo, reko, jùčé bïo velečâsni, misim käo jèl, i vâmotämo .. svétili stân - kao što i jê bílo (...). - da im dâm do znánja da ïpak ònō fàjront si, znâš. Pa ònō, nâšs, vâmo-tämo, kao òna mëni: ma dôčemo mî kao drügi púta. Reko, nèmōjte, vâmo-ta-, i nï̌ta (...)

Dok je funkcija oblika käo relativno široka, oblik je kö/ko ograničen na izvornu ekvativnu funkciju, koju rjeđe ima i oblik käo. Zbog te bi razlike käo i kö/ko trebalo smatrati dvjema česticama, a ne dvama oblicima jedne čestice.

57. A òna kö báger dümdumdümdumdümdum: kö pëši. To zòvū pëši onò .. što gräbi kao, nâš ònō käo. bánac.

58. Jâ ga brïsala kr̈pom: mástan. —Kö zäklan u pïčku: svë pò njemu čo-

59. Bez vëze ònō kui ko sad jâ i tî oväk baljèzgāmo, prîčamo (...)

60. Al òna znâ iskomplicirat tô: jôj òvō, jôj ònō, jôj ònō, jôj ònō. Pa, böže môj, kö da nísi imala djéte.

Kao što se vidi i iz prethodnih primjera, za upravni je govor kao inscenaciju originala karakteristično prepričavanje relativno dugih dionica govora, iako dionice mogu biti i sasvim kratke. Prijekaz se dužih originala jedne osobe koja nije ni adresant ni adresat prijekaza, nerijetko podržava relativno čestim ponavljanjem oblika kâže s neizrečenim subjektom i njegovih reduciranih varijanata, ali takvo podržavanje nije nužno, a ono nije ni moguće u slučaju potencijalnih originala te originala koji očito ne postoje (usp. 4. primjer). Štoviše, kod nekih je prekazivača takvo podržavanje prijekaza sasvim rijetko. Prijekaz se dužih dionica vlastita govora može podržavati oblicima reko i jâ kâžem, ali je ta- 
kvo podržavanje rjeđe nego u slučaju govora trećega lica. Naime, logično je pretpostaviti da je jedna od bitnijih funkcija podržavanja, odnosno ponavljanja glagolskih markera, u upravnom govoru prevladavanje raskoraka između deikse u upravnom govoru orijentirane na koordinate originala i koordinata prijekaza, koje se s tom deiksom ne poklapaju. Taj je raskorak najveći u slučaju govora trećega lica, pa se zato u tom slučaju i očekuje najintenzivnije podržavanje. Uz sljedeće primjere usp. također 1., 15. i 28. primjer za govor trećega lica te 56. primjer za vlastiti govor.

61. A jèdan dân dôđe käo: .. káko ste, Jäsna - níje joj bílo dóbro. 'Šês pútā sam hïtnu zvála: šês pútā. (... nerazgovijetno) I önda su döšli i izmjerili mi tlâk i dáli mi inèkciju i nëkako je tlâk päo: ëto jëdva sam döšla do frìzērke Vësne. $\hat{E}$, .. àjde donèsi nam šês pîva.

62. I ôn ti mëni pògledo gr̈lo i rëko, dä, klàsična üpala, .. viróza ōvāj, nêma tû nïkakvih prètjeranih ljëkova, misim, möšte vî kupòvat tâj Lupocët, Lekadôl, štä vëč öčete, .. al tô če vam säm pòtisnit simptóme, .. käo tô je üvjek ònō ïndividualno, möže träjat pêt ili dvàespêt dánā, pa je käo > mî čemo otvòrit bölovanje, pa vî vïdite, èl.

63. Kâže ôn mëni... Käko rek- > käko rëče mëni prije jedno dvâ tjëdna. $\hat{\text {, }}$ kâže, bíla mi je, kâže, ùnuka Íva i òna je, kâže, näzvala, kâže, ònō... Ma käk se ònō zòvē, jèbèm ti, što sam, kâže, izgùbio papire za televîzor ono?, vâmo-tämo. Reko, dòbro, dä, ï? Ma ònō, käk ònō, za ònāj dresíver, käko li ònō? Hahaha.

64. A jâ käžem, štà čemo säd čěkat i s tîm rêžjama, Bòžič dòlazi, Növa gödina dòlazi, prâznici su tû, jâ käžem, ïdemo tô rjéšt i gòtovo. ${ }^{51}$

65. (...) Ma nijje, neg ònō .. pöčela... Pa reko, Nâdo, očeš li smöki, očeš čìps, očeš li böbi, štä, vâm-täm, pikant. Eeee. 'Käk ste ònō rèkli?'P a reko, očeš li čìns, böbi ili ònō vâmo-tämo, jâ pâr stvâri näbrojo. Önda sam je zbúnio tëk: önda šútī, šút̄i .. i säd nè može ònō znâš... 'Pa möže. A štä je vëče?', kâže òvāj, znâš ònō käo.

$\mathrm{S}$ funkcijom je inscenacije originala, kao što je već rečeno, povezana i činjenica da je upravni govor jedini tip prepričavanja diskursa koji je dobro prilagođen prepričavanju dijaloga. Pri upravnom se govoru smjena originalnih govornika u prijekazu označava na više načina. Nastup novoga govornika u prvom licu, sudeći po analiziranoj građi, obično se označava univerzalnim markerima jâ kâžem i reko te nešto rjeđe nulom ili nekako drukčije. Pri tom postoje relativno velike razlike među pojedinim prekazivačima. Nastup novoga govornika u trećem licu najpotpunije se označava oblikom kâže s izrečenim subjektom (subjekt (obično imenica ili lična zamjenica) najčešće stoji iza imeni-

\footnotetext{
51 Nije jasno je li original bio govor ili razmišljanje.
} 
ce), manje potpuno i oblikom kâže s neizrečenim subjektom, a još nepotpunije nulom. Iako analiza upotrebe ovih markera nadilazi okvire ovoga rada, mislim da se ovdje o njoj ipak može reći sljedeće. Upotreba markera ovisi o duljini i dramatiziranosti prijekaza, o broju i licu govornika, o povezanosti replika unutar prijekaza i o preferencijama prekazivača. Što je prijekaz dulji i dramatiziraniji, i što je u njemu više replika, markeri će biti manje potpuni. Markeri moraju biti potpuniji radi jasnoće, ako je broj originalnih govornika veći od dva. Isto tako, potpuniji se markeri očekuju pri smjeni dvaju trećih lica nego pri smjeni prvoga i trećega lica. Osim toga, što su replike međusobno povezanije (odgovor i pitanje, logična reakcija na neki iskaz), markeri će biti manje potpuni. I konačno, postoje prekazivači skloniji potpunijemu markiranju kao i prekazivači koji vrlo često upotrebljavaju nulto markiranje smjene (sklonost se k nemarkiranju smjene, kako se čini, u znatnoj mjeri poklapa sa sklonošću k nepodržavanju prijekaza duljih dionica govora jedne osobe). Iako sami markeri smjenu na prvi pogled ne naznačavaju osobito jasno, nakon nešto detaljnije analize njihove upotrebe dolazi se do uvida da se oni upotrebljavaju u skladu s navedenim pravilima. Tako su pri prijekazu dijaloga dvaju trećih lica najuobičajeniji markeri smjene kâže s izrečenim subjektom (češće zamjenicom nego imenicom) i nula, dok je oblik kâže s neizrečenim subjektom nešto rjeđi. Pri tom treba imati u vidu da su i markeri kao kâže òna pri dijalogu dvaju trećih lica ženskoga roda relativno dobri pokazatelji smjene zato što oni nisu uobičajeni unutar prijekaza duže dionice govora jedne osobe u trećem licu (u takvim je slučajevima uobičajeno kâže s neizrečenim subjektom), nego samo na početku takve dionice. Zato nije neobično da i pri prijekazu dijaloga dvaju trećih lica istoga roda oba govornika budu zastupljena ličnom zamjenicom uz oblik kâže, tj. obično iza njega. S druge strane, u slučaju nultoga markera smjena se relativno dobro obilježava samim verbalnim i neverbalnim sadržajem. Pri prijekazu dijaloga prvoga i trećega lica kao oznaka nastupa trećega lica, osobito u primjerima visoke dramatiziranosti, u analiziranoj su građi najuobičajeniji oblik kâže s neizrečenim subjektom - koji u ovom slučaju, za razliku od prijekaza dijaloga dvaju trećih lica, sasvim dobro ukazuje na smjenu govornika - te, u slučajevima čvrste povezanosti replika, nulti marker smjene, dok je kâže s izrečenim subjektom rjeđe. Uz sljedeće primjere usp. i 11., 12., 14., 18.-20., 29., 31., 43., 49., 50., 56., 63. i 65. primjer.

66. Önda, kâže, popódne dönela tablète - nâš käo (... nerazgovijetno) tlâk òvō-ònō. Kaže nä: .. štä ste tô säd döneli? Pa kâže, môrate teràpiju. Sâd mi nè treba teràpija: dì ste cjéli dân? (...) Kâže döktor käo, .. vî môrate, kâže, göspođo, säd kad dôđete... Në käo .. nêma mjësta, na pómočni lëžaj če lëč. Kae òna, kòjì pòmočni lëžaj? Kâže, nïkaki pòmočni lëžaj. Kâže, pa önda, käo ovaj, 
mälo ste bölje, ìmā i lòšiji. E òna ïde küči. Dòbro ïdete küči: tô svë môrate ùzimat: tablète $i$ vâm-tämo, inèkcije je dobivala: môrate jëst, kâže, vöče, .. mêso, pòvrče, jèl tô svë. Kâže òna, .. štä mi niste tû dáli? Štä mi níste dáli? Kâže döktor, pa, göspođo, mî imāmo püno pacjënāta. A täko! Döktore, hvâla vam ljêpo i doviđénja i dò kūrca.

67. Tô mi je bílo, bäš je nê- > Länin täta bio jedànpūt kòd nās u úredu i käže, käo, .. käk tëbi Vlätka nïš níje (sc. pòmogla). Kažem jâ, pa käk bi: pa böže, pa da je mògla, ko da në bi. 'Ma käk níje mògla?' Onäk, pa në znam käk da vam òbjāsnim: očiglëdno níje mògla, i štä da vam jâ kâžem säd?

68. I säd ti mëne Rásim näzvao (...), kâže Räsko, äjd, pòkupi mëne - käo jâ bïo u Zdrávstvu na präksi, znâš: kòmora, tô je blizu, jèl, käo. Reko, äjd, möže, reko dóču jâ. I sä jâ dòšao, .. a Mírko: jôj, kâže, jel bi tjëli sam mëne do pijàcē - to je blizu, jèl, òd njega tämo -, òtīč sämo do pijàcē, kao ôn bi špináta. 'ko, čika Mîrko, nêma problémāa. Kae Rásim, àjde. Nâš ònō, äjd, povèdi ga, àjde.

69. Käže, jel süprug kòd kuče? Ma máršs. — Mán se mûža ù mene. — Jâ käžem, 'níje', a ôn lèž̄ na krèvetu.

70. (...) Käd mëni Ívo kâže - dòšli smo küči, bilo jèdan sât-: käže ôn mëni, jel znâš tî, kaže, da mî môramo îč dànas u grâd? Jâ kâžem, böga ti, .. štäš dànas u grádu, pa säd si bïo, jâ käžem, u grádu? Pa käže ôn mëni, pa znâš, .. Mârko je nëšto príčo da je İzvršni òdbor - znâš -, pa rëko mi je da nè mōram dôč, al ëto .. òdo jâ. A jâ kâžem, pa dòbro, äjd.

71. Jâ sam tô drugàčije rëko. Kadje mëni dìrektor rëko, .. Šìma, tîs pòkvāren. Reko, .. pòkvārena röba se nè može vï̌se kvárit. A ôn nije znäo štä če: kâže, àko si (sic) nâjstàriji stölar, tî si nâjpamètniji. Ê, reko, böga mi jèsam.

72. I päzi säd, i òna ti tô svë, znâš, nàpravi, i säd se käo ispričāva òvōm čovjeku i käže, .. dòbro je käo pa je gospòdin vǐse mòje gödište, pa me razùmije. Nâš? A ôn ti nà tô kâže: pa zäšto òna níje tû kad òna käo tô znâ rádit?

73. Ê, i önda sam mu rèkla, jesi bìo svôm òcu na gròbu? Znáči, tô je bílo tô pöslje (...) A ôn mëni nà tô rëko, jâ svôg òca drž- > nösim u š̈cu.

\section{Neupravni govor}

Neupravni se govor u spontanom osječkom govoru upotrebljava rjeđe nego upravni govor i primjera je u skladu s tim u analiziranoj građi manje. Dok upravni govor predstavlja svojevrsnu repliku originala i često ga inscenira u većoj ili manjoj mjeri, neupravnim se govorom ne replicira original, nego se prenosi ponajprije smisao poruke ${ }^{52}$ (tvrdnje, zahtjeva ili pitanja ili kompleksa od

\footnotetext{
52 Pojam je poruka važan i ovdje se svjesno upotrebljava umjesto pojma originalni iskaz.
} 
više takvih jedinica) te fakultativno neke njezine formalne osobine, tj. prenosi se prvenstveno jezgra originalnoga sadržaja, kojoj se dodaje nova ovojnica usklađena sa situacijom prijekaza. Bit razlike između funkcije upravnoga i neupravnoga govora dobro ilustriraju sljedeća dva primjera: 1. Nisi mi rekao da si pao.; 2. Nisi mi rekao 'pao sam'.'. Prijekaz se u prvom primjeru odnosi na značenje iskaza kojim se nešto htjelo poručiti, dok se u drugom primjeru odnosi na iskaz sam po sebi kao jedinicu koja ima izraz i značenje e $^{53}$. Prijekaz je u prvom primjeru adresat skloniji povezivati s nekim činjeničnim stanjem, nego prijekaz u drugom primjeru. I konačno, prijekaz se u prvom primjeru može kontrastirati s prijekazima drugačijega značenja, ali ne i s prijekazima istoga značenja, a drugačijega izraza, dok se prijekaz u drugom primjeru može kontrastirati i s prijekazima različitim samo po izrazu. Za funkcionalnu razliku između upravnoga i neupravnoga govora usp. i 35. primjer, u kojem ne bi mogao doći prijekaz u neupravnom govoru jer original nije poruka u pravom smislu, nego se izgovara pred lažnim adresatom (ocem) da bi se zavarala treća osoba. Naravno, u većini slučajeva razlika između upravnoga i neupravnoga govora nije izražena tako jasno kao u navedenim primjerima, ali to ne znači da je u većini slučajeva sasvim nebitno hoće li se original reproducirati kao replika ili kao opis poruke. Tako su u vezi sa specifičnim osobinama neupravnoga govora dionice u neupravnom govoru u prosjeku znatno kraće od dionica u upravnom govoru. Isto tako, nije uobičajeno da se u neupravnom govoru prepričava dijalog jer prepričavanje dijaloškoga originala gotovo uvjetuje inscenaciju. Iznimke ipak postoje (uz sljedeće primjere v. i 88., 98. i 99.).

74. Täk da je dèčko rëko da če, öbzirom da, jël, vïdi nörmalno da imāa ulágānja i svë, pa če pòslat svôg građevínca da mu nàpravi... — Prëdračun. Plân, dä, odnosno kòlkō bi ga dòšlo ulágānje, jel ôn ìsto môra dïč krèdīt: nêma kèša da bi izválio .. nôvce, pa da ònō, čìst ga je zanímalo kòlkō smo flëksibilni, odnosno dà li je cjéna navèdena u òglasu .. fiksna. Pa smo rèkli da se möžemo dogovòrit, nëk dâ pönudu, pa čemo vïjet.

75. A jâ ga, kak sam ga jâ tô pítala, ōvāj, jel péder ili jel nam ìmā štä za rëčc: da, ònō, mî ne osùđujemo ljúbav, da svë: ònō, spŕdala sam se, al ònō, zanímalo me štä če rëč, pa mi rëko da nísam nörmalna, da ònō...

Idući je primjer nešto drukčiji jer se u njem dijalog reproducira donekle posredno.

\footnotetext{
Naime, u neupravnom se govoru originalni iskaz prenosi upravo kao poruka ili obavijest, a ne kao iskaz sam po sebi.

53 Govoreći o značenju, mislim na sosirovski sadržaj, koji je suprotstavljen izrazu. Termin »značenje« u ovom slučaju pretpostavljam terminu »sadržaj« zato što termin »sadržaj« u ovdje predloženoj teoriji prepričavanja diskursa ima drugo značenje koje uključuje i sosirovski sadržaj i izraz.
} 
76. I säd, kak sam tô to > käo döbila pòsō, idēm jâ säd tämo pítat štä jâ säd trëam: jea säd trëam povláčit tâj záhtjev ili štä, ònō, ak je tô krénulo u öbradu ili štä, da bi mi žèna na šàlteru rèkla da ništa käo zàsad, dök ne pòtpǐšem ügovor (...)

U dijalozima se u upravnom govoru sugovornici nerijetko smjenjuju više puta, dok se u primjerima neupravnoga govora iz analizirane građe smjenjuju samo po jednom. Od smjene sugovornika u neupravnom govoru nešto je uobičajenija takva smjena sugovornika u kojoj je diskurs prvoga sugovornika u neupravnom govoru, a zatim pri smjeni sugovornika prelazi u upravni govor ili rjeđe u polunavođenje i dalje se nastavlja u tipu u koji je prešao (usp. 87., 88., 93., 94. i 124. primjer). U vezi s dužim odsječcima u neupravnom govoru postoje dva problema. Prvi se tiče same definicije neupravnoga govora, odnosno odredbe njegovih formalnih osobina. Naime, nije jasno upotrebljava li se u primjerima kao 74. samo neupravni govor ili se primjenjuje više tipova prepričavanja diskursa (o tom v. niže). Drugi se problem tiče suodnosa originala i prijekaza. Radi se o tom da se jednim dužim odsječkom u neupravnom govoru može prenositi i jedan kontinuirani duži odsječak originalnoga diskursa, ali i nekoliko kraćih odsječaka originalnoga diskursa, između kojih u originalnoj situaciji mogu postojati veći ili manji prekidi, dok se u situaciji prijekaza oni sažimaju u jednu obavijest (usp. 89. i 90. primjer). Može se pretpostaviti da se prekazivači pri prijenosu kontinuiranih i diskontinuiranih odsječaka služe barem donekle različitim strategijama, ali je to vrlo teško provjeriti jer su originali gotovo uvijek nepoznati. Sažimanje je diskontinuiranih odsječaka originala moguće i u upravnom govoru (moguće je u 39. primjeru), ali je ono za duže odsječke u upravnom govoru vjerojatno manje karakteristično nego za duže odsječke u neupravnom govoru. Naime, ako su razna odstupanja od originala karakteristična za upravni govor, ona su tim više karakteristična za neupravni govor. I neupravni govor kao i upravni može imati stvarni, nulti, potencijalni i fiktivni original. Doduše, fiktivni originali u analiziranoj građi nisu potvrđeni, ali su karakteristični za sve tipove prepričavanja diskursa, pa tako i za neupravni govor. U primjerima 77.-80. je nulti, u 82. primjeru potencijalni i nulti te u 83. primjeru jedan stvarni i eventualno jedan potencijalni original ${ }^{54}$. U slučaju je 81 . primjera riječ o hipotetičkom originalu, koji ima više smisla smatrati nultim nego potencijalnim. Za potencijalni original v. i 84. i 105. primjer.

77. I säd kö kâže da säd òna në bi .. se s Júričem dogovòrila, äjd, kǔžǐs̆, rjéšiču ti, kùžǐs̆, dâj mi sväki mjësec, nẽ znam, od tîh svòjīh nâknada ili čègā, nê znam, .. trî tì̌če kúnā, $i$ bòlī me brïga.

54 Pitanje je treba li dio mäl da pòmognu u 83. primjeru smatrati prijekazom, tj. dijelom neupravnoga govora, ili nečim drugim. 
78. Nè mogu rëč da nísam ${ }^{55}$ sìgurna da mu nè rādi u körist (...)

79. (...) I nêče rëč da në zna.

80. Ja kažem, nǐsta jâ nísam rèkla da tô níje töčno.

81. (...) jer misim, tô je ìsto ko da da kâžě̌, nẽ znam, da u əə Bêlju direktor môra bït mësar. Möš mïslit, misim: trëa bït nëko ko znâ vòdit pòsō.

82. Möžemo mî tô, .. razùmjēš, ak òni, nẽ znam, òdrāde četrdèsēt sátī, razùmjēěs, da òdrā- > da nẽ znam, trëa šezdèsēt, da im nàpīšěs da su odrádili šezdèsèt: razùmjēšs. A òpêt, nè možeš tî tû püno ni lažírat (...), pa nè moš tî napísat da je rádila stô sâtī, razùmjēš, kad si ìmō dës sátī (...)

83. Lîk ònō ispríčo žèni cjélu..., da bi joj na kràju rëko da joj niš nêče uplátit jel ònō, nëa, nëa. Kao .. mögo bi pítat djëcu mäl da pòmognu, al i tō je téško, ònō...

Budući da prijekaz u upravnom govoru replicira original, u njem se zadržava i originalna orijentacija, odnosno perspektiva, tj. deiksa se orijentira prema originalnim koordinatama. U neupravnom se pak govoru deiksa orijentira prema koordinatama prijekaza, tj. originalna se situacija adresatu prikazuje iz perspektive situacije prijekaza ${ }^{56}$. To je teza koju treba uzimati kao polazište kad se govori o odnosu deikse u originalu i prijekazu u neupravnom govoru. Naime, čak i u sasvim respektabilnoj literaturi ${ }^{57}$ opis se transformacija deikse povezanih s neupravnim govorom, iako je točan, nepotrebno komplicira, time što se ne polazi od sveobuhvatnoga pravila promjene perspektive, nego od pravila zamjene prvoga i drugoga lica trećim, koje se potom dopunjava objašnjenjem da su u neupravnom govoru u osnovi moguće i zamjenice prvoga i drugoga lica. Jednostavnije bi bilo reći da se lice u upravnom govoru određuje prema tome koju komunikacijsku ulogu osoba ima u situaciji prijekaza: ako je ona u situaciji prijekaza adresant, bit će u prvom licu, ako je adresat, u drugom, a ako nije ni jedno ni drugo, u trećem. ${ }^{58}$ Pri tom je, naravno, sasvim nevažno u kojem je ta osoba licu u originalnom diskursu. Donekle je slična situacija i u slučaju prostorne i vremenske orijentacije izražene leksičkim sredstvima. Doduše, tu je u prijekazu moguća dvojaka perspektiva, tj. deiksa u užem smislu ${ }^{59}$ (npr. rekla je da dolazi danas $)^{60} \mathrm{i}$ anafora (npr. rekla je da se to dogodilo dan ranije). Odnos

${ }_{55}$ Negacija je vjerojatno greška u govoru.

56 Valja imati na umu da su u slučaju pismenoga prijekaza prepričavanje i recepcija vremenski razdvojeni te da to može stvarati dodatne komplikacije, ali u ovom se radu opisuje usmeno prepričavanje diskursa, pa se tim problemom ne bavim.

57 Usp. Падучева 2010: 340 sq.

58 Ovdje se, dakako, radi jednostavnosti ne uzimaju u obzir specifične upotrebe pojedinih lica kao što su označavanje govornika i adresata trećim licem ili označavanje adresata prvim licem množine.

${ }^{59}$ U užem smislu zato što i (zamjeničku/nultu) anaforu smatram podvrstom deikse.

${ }^{60} \mathrm{Tj}$. jučer je rekla: Dolazim sutra. 
je deikse i anafore u neupravnom govoru zanimljiv, ali na temelju analizirane građe nije mogao biti proučen. Samo se po sebi razumije da je između originala i prijekaza moguće variranje između nominacije i deikse (npr. On je bio tamo jučer. > Rekli su mi da je Ivan bio na poslu u srijedu. ili: Ivan je bio na poslu u srijedu. > Rekli su mi da je bio tamo jučer.). U vezi s varijacijama između nominacije i anafore usp. i sljedeće primjere.

84. Nï̌st, näzvala šëfa i rèkla, šëfe, što se mëne tîče, ak möžemo retroäktivno ònō pomàknut tô svë, da sam käo rànije potpísala ili nèšto: smánjite mi òtkazni rök da mògu pòčèt rádit.

85. A čüjem, kâže mi mäma tvòja da si tî ìsto pütovo u ponèdljak küči, jèl? (...) I bäš s tvòjōm mämom prîčam nëki dân, i kâže, dơšō si i tī bäš küčci tâj dân.

U analiziranoj je građi pronađen samo jedan primjer za koji bi se moglo tvrditi da se leksički izražena vremenska deiksa u njem orijentira prema originalnim koordinatama. Doduše, riječ je o leksemu säd, koji nije samo priložna zamjenica, nego i čestica (konektor i rečenični modifikator), a upotreba bi se u dotičnom primjeru mogla smatrati graničnom između priložne i čestične. Osim toga, sam primjer ima neke elemente nekarakteristične za neupravni govor, npr. imperativnu riječ äjd.

86. I önda je ôn dòšo do záključka da jâ ùkljūčim mašinu i da önda stvorimo köntraèfekt, da òvā mašina tëra vödu, jel mi je .. zàdnjē vrjéme, kad râdi mašina, u jèdnōm mòmentu mi krêne vòda iz umivaoníka göre, pa sam jâ skúuzila, tô mìslim da níje nörmalno, i ôn kâže, äjd, nek jâ säd ükljūčim mašinu, pa čemo vïit, mòžda ga pòtera na drügu strânu.

$\mathrm{S}$ tvrdnjom da se u neupravnom govoru deiksa orijentira prema koordinatama prijekaza ipak se ne slaže upotreba glagolskih vremena u prijekazu neupravnoga govora ne samo u Osijeku, nego i općenito u slavenskim jezicima. O tom v. niže.

Pri neupravnom se govoru, $\mathrm{u}$ skladu s njegovom funkcijom, u prijekaz $\mathrm{u}$ pravilu ne prenose elementi načina priopćaja, tj. ni ekspresivno-dijaloški elementi ni jezik i dijalektalne osobine ni govorne vrednote i drugi neverbalni elementi koji prate komunikaciju. Neki se takvi elementi transformiraju, većina ih jednostavno izostaje, a neki se moraju prenijeti u upravnom govoru. Tako se imperativ u neupravnom govoru zamjenjuje prezentom, krnji perfekt punim perfektom, a i originalnomu vokativu u neupravnom govoru često odgovara dativni objekt uz glagol govorenja, iako bi bilo pogrešno reći da se vokativ originala pri neupravnom govoru u prijekazu zamjenjuje dativom, zato što dativ uz glagol govorenja stoji neovisno o vokativu u originalu. S druge strane, mnogi usklici, čestice kao $p a$ i ali, etički dativ i mnogi neverbalni elementi jednostav- 
no se izostavljaju pri pretvorbi u neupravni govor, dok se optativ većinom mora prenijeti u upravnom govoru ili nadomjestiti na neki način koji izlazi iz okvira prepričavanja diskursa. Doduše, iznimno se neki specifični elementi načina priopćaja mogu unositi u prijekaz, ali takvi se prijekazi ne mogu okarakterizirati kao »čisti« neupravni govor. Uz sljedeće primjere usp. i 86. primjer.

87. Nëšto je > nëšto je rëko u smîslu käo .. da smo mî > kàkī smo mî: .. nïkad ništa òd nās käo nëšt. I jâ sam önda njëmu rèkla käo, .. àjde (...), pa sam rèkla ovāj, .. àjde prôbaj mälo vïdjet s drügim ljúdima (...)

88. (...) i jâ sam se, nâš, ònō prèdstavila ī täk, säm sam rèkla evo da mi je drâgo što je dòšla prömjena, da ònō .. je bílo krâjnje vrjéme, ali da ìsto tàko дəə znâm da jēe da níje bäš dòšō u nâjbolju situáciju i da mu zàtō žèlīm püno, püno srëče jer če mu trëbat, i püno strpljénja, i ôn ònō käo hvála, hvála (...)

89. Pr̀vō i òsnōvno, što i sâm kâže, níje ni mìslio da je tàko kako jê: ònō käo kroz növine je svë bílo krâsno-dîvno što je vïdio; nàčuo jê da ìmā òdrēđenih problémā, ali bäš da je situácija - säd nëki dân, kad je òvāj .. koléga bïo kòd njega, je rëko 'bljeea' ${ }^{61}$, táko da je.

Prijekaz u neupravnom govoru čine zavisne izrične, zahtjevne i upitne rečenice $^{62}$ koje većinom ovise o predikatnim markerima prijekaza, a uz njih prijekaz može markirati i čestica käo. Predikatni se markeri prijekaza u neupravnom govoru, za razliku od onih u upravnom govoru, mogu zvati i uvodnim predikatima zato što u neupravnom govoru nije kao u upravnom uobičajeno da se markeri ponavljaju unutar prijekaza i tako ga podržavaju. Bitna je karakteristika neupravnoga osječkoga govora to da je prijekaz obično jasno markiran uvodnim predikatom. Drugim riječima, u Osijeku i okolici nije uobičajeno prepričavanje diskursa rečenicama sa $d a$ bez glavne rečenice, tj. bez uvodnoga predikata. Doduše, u građi postoji određen broj primjera u kojima prijekaz u neupravnom govoru nije neposredno uveden predikatnim markerom (uz sljedeće primjere usp. 11., 51., 75., 84., 127. i 135. primjer), ali u takvim je primjerima većinom riječ o labavijem nadovezivanju na već započet prijekaz.

90. I pöslje tôg önda käo pòprāvka.. tôg drügog .. su me zváli da me pítaju däl bi > däl sam zainterèsīrana, ali za drügo râdno mjësto: në òvō za koje sam se prijávila, nëgo .. računovòdstvo i òdjel pödrške poslovánju, šta göd tô bílo: da im trëba nëko, odnosno tôj žèni koja mi je bíla na drügom räzgovoru, njênom òdjelu, ōvāj дəə za počétak na gödinu dánā, ali ak .. jâ büdem $i$ òni zädovoljna > i òni zädovoljni, da ōvāj, da imāa próstora da käo za .. òstat, pa täk da jâ pr̀vōg drügog stärtam...

${ }_{61}$ Navedeni zapis samo donekle dočarava izraz gađenja koji je teško fonetski opisati.

${ }_{62}$ Takva je tročlana podjela donekle pojednostavnjena, ali je praktična i za ovaj rad dovoljno detaljna. 
91. Zvála me, pitala me jesam zainterèsìrana za to drügo râdno mjësto, da dôđem, odnosno, kad prikupim òdrēđene papíre, da dôđem, pa če ōvāj, pa če > pa če mi svë rëč, kùžřs̆.

92. (...) a ôn, .. kö znâ, .. jâ në znam je- > ak je i biò na kòjēm räzgovoru, käk se pòstavio: da je ôn, në znam, svêti Pëtar i da ònō, rádiču ti, al néču ti rádit, ònō, zā .. minimálac (...)

93. Mëni jê (...) Släven (...) rëko da òvī u Zágrebu razmiśsjaju da me vrâte: käo nè može ôn sâm, trëba mu nëko da je u úredu vâmo-tämo, i òni su se käo .. bëz razmiśljānja ùhvatili mëne, ònō: prìā koju bi vräčali sam jâ bläablâ. I jâ sam rèkla, pä dòbro: jâ ìmām säd tû pâr nätječaja, vâmo-tämo, .. ak bü- > nëk me zòvū, pa ču vïit štä mi pònude. Pä je önda bílo käo imāšs pòslōvno úvjetovani, pa ònō, nè smiju nïkog - .. òdnosno òni čăk mïsle da nè smiju ni-ni .. tëbe zapòslit, koji si döbio òtkaz, a mògu: náči, ònē koji su dáli > döbili òtkaz, njîh mògu zapòslit, nè smiju nïkog drügog prije isteka od šês mjesécī.. Ōvāj .. ïl, në znam, dä bi mòžda önda smïslili da me prìjāve na nëš drügo ili na pôl râdnog vrëmena il nëšt. Rëko, okêj. Ne > sämo nek me zòvū, pa ču jâ viït.

94. Òna je ôvaj rèkla da joj je tô pr̀vī käo özbiljni klijent, .. îako je rèkla pöslje tôga da ga nè može bäš (...) I önda .. kâže, nè može ga prokljúvit, .. zato što säd .. ìdē s njîm u Vï̌njevac vïdjet nëku küču koja je, në znam, dvápūt mänja i onäk u Višnjevcu je, i uöpče joj nije jäsno štä trâži: da je tô pòtpuna jèdna suprótnost, znači näša küča, ònō, u òvōj čëtvrti i tòlkà vèlika sa ònìm tämo, i da ga nè može odgonétnut, al käo... — Tô je mälo nëobično. — Jâ kâžem, jâ jöš mänje.

U nekim je hrvatskim govorima neupravni govor bez uvodnoga predikata znatno češći nego u osječkom. Štoviše, u takvim govorima veznik da funkcionira kao svojevrstan univerzalan marker neupravnoga govora te u toj funkciji nerijetko dolazi također pred upitne rečenice i pred česticu nek(a) u zahtjevnim rečenicama, a tako i poslije veznika nekih zavisnih rečenica. ${ }^{63} \mathrm{U}$ osječkom neupravnom govoru uvođenje upitnih rečenica sa da (tip da hoće li on i da što) nije

63 Prema tome, u takvim su govorima uobičajene rečenice kao: Da on ima nekog posla pa da će kasnije doći. (izjavna), Da (neka) dođem kod njih na ručak. / Rekli su mi da (neka) dođem kod njih na ručak. (zahtjevna), Da hoće li se on ljutiti. / Rekao je da hoće li se on ljutiti., Da što će mi to. / Rekao je da što će mi to. (upitne), a uz to usporedi i ranije navedeni primjer Ne daju mi bicikl jer da sam premalen.. Takve su rečenice tipične za Istru, Primorje i Dalmaciju (za Istru mi ih potvrđuje David Mandić, za Ugljan imam svoje podatke, za Knin mi ih potvrđuje Ankica Čilaš Šimpraga, za Split Dijana Ćurković i za Dubrovnik Orsat Ligorio). U Katičićevoj se sintaksi (Katičić 1991: 355 sq.) navodi više sličnih primjera iz Krleže, što bi moglo navesti na pomisao da je taj tip prepričavanja diskursa karakterističan i za unutrašnjost Hrvatske. Ipak, prema Mati Kapoviću (usmeno) dotične konstrukcije nema u zagrebačkom govoru, a u Krleže će ona biti knjiška. Rasprostranjenost bi toga tipa prepričavanja diskursa u govorima valjalo detaljnije istražiti. 
potvrđeno u analiziranoj građi, a ako je eventualno moguće, svakako nije uobičajeno. Isto vrijedi i za rečenice sa $d a$ iza zavisnoga veznika (tip jer da sam premalen). Kolokacija da nek je jednom potvrđena, ali se i ta potvrda može smatrati rezultatom svojevrsnoga ispravljanja u govoru.

95. İ önda smo s'dogovòrili s njîm zâpravo dā nek büdu zákōnske otpremnìne i nek büde pòslōvno úvjetovani radi nâs, da se möžemo prijávit na bìrō.

Za neupravni je govor karakteristično da set predikatnih markera prijekaza varira ovisno o tom uvode li se izrične, zahtjevne ili upitne rečenice. U upravnom je govoru međuovisnost između tipa rečenica i markera prijekaza znatno manja. Nepredikatni se pak marker käo upotrebljava podjednako u svim tipovima rečenica prijekaza u neupravnom govoru (usp. 76., 90., 94., 98., 118., 127., 129., 130. i 139. primjer). Prijekaz u neupravnom govoru koji započinje izričnom rečenicom, prema analiziranoj građi, najčešće uvodi perfekt glagola rëč u jednini i množini. Markeri se u množini znatno bolje slažu s prijekazom u neupravnom govoru, koji je relativno apstraktan, nego s prijekazom u upravnom govoru, koji je konkretniji (uz prijekaze u upravnom govoru oni, ako ne računamo donekle specifičan 39. primjer, $u$ analiziranoj građi nisu potvrđeni). Uz sljedeće primjere usp. i 74., 75., 80., 87.-89. i 138. primjer.

96. I önda sam jâ, .. tâj pût kad mi je rëko da nêma šänse da jâ ìmām djècē, .. onda sam izašla vân, .. bíla sam tòtālno šòkìrana...

97. Täk da sam jâ njû nâzvala i rèkla da néču ni u pétak dôč.

98. Önda smo mu rèkli da nam je bïtno dā .. da nas, ònō, ne zàkine u smislu .. zákōnske otpremnìnē, .. da ne očèkujemo vǐše, .. ako je drúštvo u tàkōm, jël, rasúlu u kàkōm jê, al da önda ni ne očèkuje da potpisujemo spörazumni s njíme, jer, ònō, sa spörazumnim se käo dòbīja mälo vǐse, jël.

99. Ijöšs su oni > na räzgovoru sam jâ pitala - kao pî̌se 'na òdrēđeno (zâmjena)' - jel tô bölovanje, pörodiljni, štâ: štä znâči òdrēđeno. I òni su mëni rèkli käo da në znaju, .. da je za tàkō vëliki nätječaj téško > téško procjéit na kòlkō dügo.

$\mathrm{U}$ analiziranoj je građi kao marker neupravnoga govora koji počinje izričnom rečenicom, nešto rjeđi prezent od kázat $(i)^{64}$ (kâžem, kâžeš, kâže, kâžu) uz koji obično stoji subjekt. Ipak, u neupravnom je govoru taj prezent u odnosu na druge glagolske markere prijekaza u prosjeku zamjetno rjeđi nego u upravnom govoru. Osim toga, taj prezent većinom nije historijski kao u upravnom govoru, nego je obično riječ o tipu prezenta koji se u literaturi kategorizira kao podvrsta

${ }^{64}$ Glagol je kázat(i) u osječkom govoru u infinitivu i pridjevu radnom te od njih tvorenim složenim oblicima vrlo rijedak, a ne prevladava ni u imperativu, pa bi bilo točnije tvrditi da je kâžem supletivni prezent od rëč $(i)$, utoliko prije što se prezenti kao **rečem ili **reknem u osječkom govoru ne upotrebljavaju. 
svevremenskoga prezenta ${ }^{65}$, iako se radnja koju označava, u pravilu ${ }^{66}$ dogodila jednom ili više puta u nekom konkretnom vremenu, ali se zbog svojih konotacija s jedne strane i posljedica s druge percipira kao svevremenska. Riječ je o prezentu kao u primjerima Tata kaže da se to ne smije dirati. ili Protagora kaže da je čovjek mjerilo svih stvari., a ja ga ovdje prema Uvodu u rusku aspektologiju ${ }^{67}$ zovem ekspozicijskim prezentom. Na to da se ovaj prezent razlikuje od historijskoga, ukazuje i njegova prisutnost u kontekstima u kojima historijski prezent/pripovjedni režim nije moguć, kao u zavisnim rečenicama u 100. i 102. primjeru. Osim toga, na nenarativnost ukazuje i činjenica da je subjekt (imenica ili lična zamjenica u kojem god licu) uz ovaj prezent, kao i općenito uz glagole koji uvode neupravni govor, obično pred glagolom. Ekspozicijski prezent nije osobito tipičan kao uvod u zahtjevne rečenice (u građi postoji jedan primjer). Uz sljedeće primjere v. također 7., 85. i 143. primjer.

100. Čëkaj: ònāj ko kâže.. dā níje završsio fakùltèt zađàbē, a ljûdi sa prâvnim fakultétom pròdaju jája na pijàcu, tâj në da je iskomplèksīran, nego je tòtālni egomànijak.

101. Štö, dôče rádit, razùmjēš, .. stäviče pr̈st u üvo mòžda ili če rádit-ïako, òni kâžu da je òna vòlila rádit i da je òna üvjek njïma ìzvūkla $\bar{\imath}$.. Kònzumove bónove i bòžičnice $i$ štä ja znâm .. - ōvaj .. i i štä, do miròvine i bòlī ju đön.

102. Al ôn ònō, sväki pût ìmjeri bébu, ònō käo .. svë je .. srëdnje: käk da käžem, težìna i... Käo níje prëvèlka, níje prëmála. Kad ôn kâže da níje prë-.. mislim ni prëmála väld čòvjek znâ ònō.

103. Jer vî säd > jèdnōm gòdišnje da nàpraviš əə kr̂vnu slïku i da nàpraviš, štä ja znâm, tâj ùrīn, vïdiče se ako ti je nëšto... Jèl? Ali mî tô nêmamo vrëmena. Al za àuto ìmāmo vrëmena. Jel níje tàko? — Tàko je. Al tô je kod svîh tàko. Pa jâ kâžem da je tô ljënost: ništa drügo .. več klàsična ljënost.

Neupravni govor s početnom izričnom rečenicom uvode i drugi oblici od rëč: futur, imperativ, infinitiv (obično s modalnim glagolima) i izrazi tipa da bi mi ôn rëko, dok prežitak aorista reko nije uobičajen, i nema ga u analiziranoj građi, iako je vjerojatno moguć (uz sljedeće primjere usp. i 76., 78., 79., 83. i 133. primjer).

${ }_{65}$ Potvrđen je i prezent za futur II (7. primjer) i prezent u irealnoj pogodbenoj rečenici (81. primjer). U analiziranoj građi nema nijednoga primjera s historijskim prezentom od kázat/rëč koji bi uvodio neupravni govor koji započinje izričnom rečenicom, ali se takvi primjeri mogu zamisliti.

${ }_{66}$ Iznimke su primjeri kao knjiga piše, pjesma govori o i neki drukčiji kao 100.

67 Usp. Зализняк, Шмелев 2000: 29 (ruski je termin настоящее экспозиционное). Taj se prezent pod drugim nazivima izdvaja i u latinskoj gramatici. U Menge 2009: $\S 132,4$ i 5 ovaj se prezent zove pregnantni prezent (prägnantes Präsens), a kad se odnosi na tvrdnje autora koji se čitaju, literarni prezent (literatorisches Präsens). Hrvatski termin literarni prezent i latinski ekvivalent praesens litteratorium nalazimo i u Gortan, Gorski, Pauš 1985 (bilješka u § 522). 
104. Jâ vîčem, ôn kâže, pa tëbe čùju, kâže, ljûdi nà ulici, jes tî nörmalna? Nâš ònō? Kaže, rëče ljûdi da se sväđamo.

105. Jesam natèčena? — Mä jèsi... Rèci da joj je jèzik natèčen.

106. Štä tî säd höčěs rëč, da jâ trëam îč konobárit?

Kao uvod u neupravni govor s početnom izričnom rečenicom rjeđe dolaze drugi predikati. Neki od tih predikata mogu uvoditi i izrične i zahtjevne rečenice. Takvi su, na primjer: jávit, pòslat pöruku ${ }^{68}$, napisat, písat (bezlično), dòbit mêjl. Drugi također mogu uvoditi i jedne i druge rečenice, ali su prilagođeniji izričnim nego zahtjevnim rečenicama, npr.: iskomentírat, brûndat, bït, bït $u$ novinama, dòbit informáciju. Konačno, postoje uvodni predikati čija se semantika ne slaže sa zahtjevnim rečenicama, nego samo s izričnima. Ti predikati uglavnom ne mogu markirati ni upravni govor, a mogu se podijeliti u tri skupine: 1. predikati koji se odnose na tekstove u kojima nisu uobičajene zahtjevne rečenice (imat u ügovoru i sl.); 2. predikati koji označavaju operiranje činjenicama (stvarnim ili fiktivnim) (làgat, tvŕdit, srät, príčat, pričat se, krûže prîče, smátrat, imat informáciju itd.); 3. predikati percepcije, odnosno doznavanja (čüt, nàčut, vïdjet, pročitat, sàznat itd.). Uz sljedeće primjere v. i 17., 95., 120., 132., 133., 135. i 178. primjer.

107. Jâ sam u ponèdljak njôj jávila da jâ néču dôč, òvō-ònō...

108. I önda, .. kak je òna mëni pöslala pôruku ònō da je príčala s pâr ljúdī (...)

109. Jâ, kad sam tô pröčitala, jâ nísam znäla kö pïje, kö plâča: znáči onäk, pr̀vō je napísala da ìmā dvïje kupaónice, a ìma trî, .. në znam štä je napísala, da ìmā klíme, nêma klímē...

110. I čẹkam säd da tô büde, da vìdim kä če bït testírānje, jel tû isto pîše da je .. testírānje öbavezno, i önda ōvāj... (...) I I.. vëč sam jâ köntala, tô je nëko vëč zàposlen, štä ja znâm, nëam pójma, na kràju sam döbila informáciju da su zaprímili cètristo zámōlbi: trïsto seamdëst $i$ nèšto zámōlbi $i$ da òni jöš üvjek tô sortíraju, i ònō öče > ono präve .. üži krûg ili štä göd...

111. Doduišēe, ôn kâže, kak je tô u növinama üvjek bílo i na televîziji òno da mî .. rástēmo i cvàtē nam prómet $i$ svë, nâš...

112. S tîm da je ù tōj käo zàdnjōj bílo da > da je öbveza vräčanja njê na pòsō jel je u bíti nézákonit tâj òtkaz .. koji smo joj dáli.

113. Ôn je ù tōm svôm ügovoru .. ìmao tô da, nači, .. preùzima odgovórnost à vòđēnja (...) dō > völjom dòbrōg gospodàrstvenika, razùmjēš.

${ }_{68}$ Ovdje predikatima nazivam i glagole s jedinicom koja se može smatrati objektom ili priložnom oznakom. 
114. İšla sam i $n->\bar{l}$ na rektòrāt, kúžiš, i täm sam ònō bäš ïzravnu informáciju ìmala da je zà tū cüru nëku ònō, präktički ïmenom i prézimenom.

115. Kad je Jánja príčala da je bíla kòd njē, pòjela kïlu këksa...

116. Säd nam krûže prîče da ìmā dèčka.

117. Misim znâs: säd se vëč prîča po po fîrmi da je to nàpravila da əòni djêle tâl.

118. Za što je Àntunu brät pöčeo srät käo da su döbili čètristo kúnā st- > vòde.

119. Ina kràju sam säznala dajēōvāj zâmjena vàljda, daje tâ administrâtorica slòmila rûku i da je nêma vëč dvâ mjëseca $i$ da òni në znaju kòlkō njê säd dügo nêče bït, täk da stvárno në znaju na kòlkō dügo .. če čé...

120. Čüla je od Vësne frizēerke da ìmā tämo bàtkōva jëftino i štä jâ znâm tê fóre käo.

121. S tîm da vïdjela sam, bäš Döm zdrâvlja ìmā svë transparëntno, svë zaposlenike navèdene, i vïdim da ìmā trî administrâtorice.

Primjera je u kojima prijekaz u neupravnom govoru počinje zahtjevnom ili upitnom rečenicom, u analiziranoj građi znatno manje. Uz zahtjevne su rečenice potvrđeni sljedeći predikati koji mogu uvoditi i izrične rečenice: više puta perfekt od rëč, nešto rjeđe prezent kâžem/kâžě̌ /kâž $e^{69}$, te po jednom $r e k o^{70}$ (zajedno s kâžem), dogovòrit se i dôč do záključka. Dvije zahtjevne rečenice uvodi i glagol zvät za koji nisam siguran može li u osječkom govoru uvoditi izrične i upitne rečenice ${ }^{71}$. Osim toga, potvrđene su i zahtjevne rečenice uvedene glagolima trážit i mòlit, koji ne uvode izrične rečenice, i jedna zahtjevna rečenica uvedena glagolom pitat, koji obično uvodi upitne rečenice, ali se primjeri s takvim uvodnim glagolima vjerojatno ne mogu smatrati sasvim tipičnim neupravnim govorom. Naravno, može se naći i poneka zahtjevna rečenica koja nije neposredno uvedena nikakvim glagolom. Uz sljedeće primjere usp. i 83., 86., 91., 95., 139. i 125. primjer.

122. Ôn je rëko nek dôđem, pa čemo zatvòrit bölovanje, pa dòbro.

123. Kak sam jâ rèkla täti da če tâj .. dèčko dôč, da ôn büde kòd kuče, jer jâ në znam .. püno töga, a sïgurna sam da če òvāj imat pitānja.

${ }_{69}$ Prezent je dvaput historijski (86. i 124. primjer), jednom ekspozicijski (139. primjer) i jednom $\mathrm{u}$ irealnoj pogodbenoj rečenici (125. primjer).

70 124. primjer. To je jedini slučaj markiranja neupravnoga govora oblikom reko u analiziranoj građi.

${ }_{71}$ U govoru Kukljice na Ugljanu glagol zvâti uvodi sve tri vrste rečenica prijekaza u neupravnom govoru kao i »obični« glagoli govorenja. 
124. I ovaj .. jâ kâžem əə Märinu, reko, da vïdi sa Dànikom ka če òna dôč iz Ösjeka, jer če òna dõč pò tāj kòlāč... Kâže, dogovòriču se jâ s njôm. Äj dòbro je.

125. Pa nï̌ta, pa tô su bàpskē prîcee. Jôj, käk ste mògli nàsjest? — Ma jôj, pa bílo mi je tàkō da ònō .. ma dâj .. da mi kažeš da pöpijem... — Góvno, da òprostite...

126. I önda su me zváli pönovo da dôđem jöš jèdnōm.

127. Jöš me tô tâ šèfica kao mòja administrácije, tâ vjëštica zvála käo .. da ìmām u vídu kòlkō je njôj tô téško säd käo .. òsobno, jël, nàzvat nëkog i zvät ga kòlkō ga žèlī da rádi s njôm, në znam štä... Söri, brätē: kúžiš, tô je tvôj pròblèm, misim... — Kòlkō je njôj téško. —Zámisli kao da > käo da je slüčajno nè odbijem, znâš, jel je njôj trëalo jâko püno, jël, da òna öpče pregrizè, da òna nëkog zòvē, kúžiš, da dôđe rádit, ònō...

128. İsto tàkō te i ôn angažirō, odnosno trážio te dā ga provèdēš. (...) I ôn je trážio tô nèšto da òna njëmu dâ (...) i ôn je mólio njû dā joj > da mu tô dâ da ôn tô dâ svôm građevináru (...)

Upitne rečenice u neupravnom govoru u analiziranoj građi uvode samo glagoli pitat i ispitívat. Doduše, postoje i dva primjera u kojima je upitna rečenica uvedena glagolom zanímat, ali to neće biti sasvim tipičan neupravni govor. Glagoli govorenja kao rëč, sudeći prema primjerima, ne mogu uvoditi prava pitanja u osječkom neupravnom govoru ${ }^{72}$, nego samo retorička pitanja kao u 87 . primjeru. Doduše, takvi i drugi slični glagoli mogu uvoditi prave zavisne upitne rečenice (npr. rëko / jávio mi je / znâm / čüo sam kö je pobjédio., rèci mi jesu dòsli.), ali u takvim primjerima nije riječ o neupravnom govoru. Ima i upitnih rečenica prijekaza neupravnoga govora koje nisu neposredno uvedene glagolom. Uz sljedeće primjere usp. i 74.-76., 90. i 91. primjer.

129. A.: A nà tō níje nïšt rëko? — B.: Pa pitō je sämo käo jel póstoji mogúčcnost, a önda je skúžio da tämo imā tô da se möže i ovaj, i pròvest i svë, al njëga je vǐše zanímalo däl se möže nëkako odvòjit od súsjēda, òdnosno, ònō: .. ôn bi sëbi nëš täm svòje i ôn bi si stavio ònāj sa kä nèšto što kontròtìra potróšnju .. nëšto, në znam. - C.: Kalòrimetar? — B.: Në> ë tô, dä... Óvāj... Pitō je kòlkō je otprílike ràčūn za grïjanje po zimi i...

130. Kâže pitō je òvāj näš súsjed njênu mämu käo jel ïstina: návodno se käo (...)

131. Pa zäšs s' tî mëne, Vlätka, nëki dân ispitívala kòlkō vòdē ìmāmo i tô?

${ }^{72}$ U nekim je drugim hrvatskim govorima to moguće. Tako se u Kukljici na Ugljanu prava pitanja mogu uvoditi sa ûn govörilje rëko (da). 
Kao što se vidi iz primjera, izrične se rečenice prijekaza u neupravnom govoru gotovo uvijek uvode veznikom $d a$. Veznik je $k a k(o)$ koji uvodi izrične rečenice neupravnoga govora, $u$ analiziranoj građi zabilježen nekoliko puta u tri primjera. Na temelju je triju primjera teško reći postoji li između veznika $d a$ i kak u ovom slučaju neka funkcionalno-semantička razlika. Ipak, čini se da veznik kak ukazuje na smanjenu preciznost i konkretnost pri prenošenju originalnoga sadržaja. Na to upućuje i izraz sëam pútā u 133. primjeru, gdje se očito prenosi bit nečega što je više puta izrečeno u raznim varijacijama. Uz sljedeće primjere usp. i 160. primjer.

132. Dòbro, bílo mi je jèdīno olakšánje dā > što je ôn onàko .. prílično samoùvjereno ònō .. iskomentírō kak bi ôn garsonjéricu, náči, ònō...

133. Òna nêma vrëmena, i òna je sëam pútā rèkla kak òni némaju vrëmena, kak su òni zàposleni. (...) nači, nísi mi se jávila, nïkom òd nās, nije nas uöpče > дəa nëamo pòvratnu informáciju od dèsētog mjëseca, otkad je òglas stävljen, i säd mi jöš tû brûndaš kak nêmaš vrëmena. (...) Né misim da trëba làgat ili në znam štä, al önda s- > ak se nè moš angažirat, réci i doviđénja, a në .. sëam pútā rëč kak je > käk je u gûžvi (...)

Uz navedene primjere usp. i sljedeći, u kojem nije riječ o tipičnom neupravnom govoru.

134. I tî, kako göd da nàmetneš nëku drügu tému, ôn se üvjek vräča na tû (...) svòju frustráciju kako je óvdje grôzno, kako je óvdje kätastrófa kako .. nâš, óvdje nêma budúčnosti, kako...

Duži prijekazi koji započinju kao neupravni govor mogu sadržavati više izričnih rečenica koje sintaktički, te u nekim slučajevima vjerojatno samo semantički, zavise neposredno od rečenice koja sadrži predikatni marker prijekaza. Ovdje takve rečenice nazivam primarno zavisnim izričnim rečenicama. U nekim je takvim rečenicama formalno izražena veza s rečenicama iste razine zavisnosti, tj. uvedene su sastavnim, rastavnim, suprotnim ili kojim drugim nezavisnim veznikom, a u nekima nije. U nekim prijekazima veznik $d a$ stoji na početku, odnosno neposredno iza nezavisnoga veznika, svake takve rečenice, u nekima stoji samo na početku nekih takvih rečenica, a u nekima samo na početku prve. S obzirom na to da je sintaktička podređenost predikatnomu markeru prijekaza jedno od bitnijih obilježja neupravnoga govora, a ona se najjasnije izražava veznikom, u slučaju kad neka od primarno zavisnih izričnih rečenica, osim prve, ne započinje zavisnim veznikom, nije jasno radi li se o »čistom « neupravnom govoru ili o kombinaciji neupravnoga govora s nekim drugim tipom prepričavanja diskursa, ponajprije s polunavođenjem. Neki se takvi primjeri svakako mogu smatrati kombinacijama dvaju tipova, dok je neke vje- 
rojatno praktičnije smatrati »čistim« neupravnim govorom. Međutim, na pitanja gdje bi prolazila granica između kombinacije i čistih tipova i s čim je povezana prisutnost ili odsutnost zavisnoga veznika, u okviru ovoga rada nije moguće odgovoriti. Uz sljedeće primjere usp. i 74., 88., 98. i 99. primjer.

135. (...) jer òna smâtra da je òna tâ koja nâjviše, znâšs, əəə zaslùžuje, da je òna strùčnā (sic), da, nâš. Da ôn säd əo da ôn nema pójma, da ôn në zna jel bi ôn píškio il kákio, da je ôn päo s krüške...

136. Vòzio nas je nëki klïnac .. i rëko je, kùžǐš, da ôn .. ònō, nêma žènu-djéte, i ôn uglàom râdi nòčne i da ôn sëbi navúče sa nòčnìma, .. kùžǐš, .. šês mîlja kúnā nëto.

137. I jöš täta kâže da je tô nèšto komplicirànije tâj, zbog tôg lòkātora. (...) Täk da je ôn tô tämo nëš käo pòpravljo, a ònō... İako kâže da je i zà njega čăk vëč tô prekomplicîrano, al äjd, öbzirom da znâ o čëm se râdi, kad je vàljda sùdjelovo pri izgrádnji i svèmu, òvaj, önda če käo próbat, pa ak nè bude mögo, zväče tôg nëkog svôg.

Zahtjevne se rečenice u neupravnom govoru, kao što se vidi iz primjera, uvode sa $d a$ i nek/nëk uz jedan primjer sa $d \bar{a} n e k$, koji je vjerojatno omaška u govoru. U analiziranoj je građi češci veznik $d a$. On dolazi iza svih predikatnih markera te pri nadovezivanju unutar prijekaza. Veznik nek je rjeđi, a u analiziranoj građi dolazi samo iza oblika glagola rëč (uključujući i prezent kâžem) i pri nadovezivanju unutar prijekaza. S tim se u vezi u osječkom neupravnom govoru zahtjevne rečenice uvedene veznikom nek vjerojatno mogu smatrati općenito nešto samostalnijima nego zahtjevne rečenice uvedene veznikom $d a$, a tomu u prilog govori i činjenica da su one formalno slične imperativu trećega lica. Pitanje je ovisi li upotreba veznika da i nek o licu glagola u zavisnoj rečenici. Između prvoga i trećega lica u primjerima nema razlike, a zahtjevne rečenice u drugom licu u analiziranoj građi nisu potvrđene. Zahtjevnu rečenicu u neupravnom govoru uvijek mora uvoditi bilo $d a$, bilo nek. Upitne se pak rečenice u neupravnom govoru uvode kao i ostala zavisna pitanja.

Za izrične je i zahtjevne rečenice u neupravnom govoru karakteristično da se neki njihovi dijelovi mogu nalaziti pred veznikom koji ih uvodi. Kako se čini, pojava je karakterističnija za zahtjevne rečenice nego za izrične, ali to bi valjalo provjeriti na većem korpusu. Isto tako, rečenica zavisna od takve zahtjevne rečenice koja teži inverziji, obično stoji pred cijelom zahtjevnom rečenicom. Sudeći prema primjerima, u slučaju izričnih rečenica takve zavisne rečenice koje teže inverziji, obično dolaze unutar rečenice s ponavljanjem veznika $d a$ iza zavisne rečenice. ${ }^{73}$ Primjera je ipak premalo da bi se na temelju njih

${ }^{73}$ Naravno, postoji i varijanta u kojoj veznika primarno zavisne izrične rečenice uopće nema kao u 137. primjeru. 
moglo donijeti pravilo. Veća se sloboda rečenica u neupravnom govoru u odnosu na ostale aktantne rečenice s jedne strane vjerojatno može povezati s tim što neupravni govor ipak i formalno donekle odražava slobodu samostalnoga govora, tj. onakva govora kakav služi kao original, a s druge strane, kolebanjem govornika između mogućnosti da original priopći kao obavijest koju je od nekoga čuo ili kao činjenicu neovisno o načinu na koji je došao do nje. Uz sljedeće primjere usp. i 83., 86., 89., 128. te 74., 90. i 91. primjer.

138. A stvárno, jädna žèna i u Zágreb i .. jel rèkla čäk $i$ u Rjéku da je išla; ma në znam, i üzduž i pöpreko su je izrezali, svë u rédu, i ni dân-dànas žèna nêma.

139. (...) Jer sam jâ ovaj s njïma prije .. - kölko bi mòglo bït-, tjëdan dánā razgovárao: kâže svë da mëtnemo na pópis, .. ko göd je käo zagùbio, izgùbio, nije döbio, vâmo-tämo, i da im odjèdnōm kao, da poošaljemo kao slüžbeno, jèl: da če svï dòbit.

140. (...) òdnosno da mòžda čäk nè mōram ni dòlazit, neg nëk se jâ njëmu jâvim na mêjl, kad jâ pòtpĭšem ügovor, da mu pöšaljem käo slïku, òdnosno .. në znam, käo skën ügovora da ôn tô vïdi, pa če me ôn upútit däl ònō štä trëbam il në.

141. Znâš štâ: rèkli su mi, kad ìmāš tàko grlòbolju i tô, da izbjègāvaš mljéko i mljêčne pröizvode.

142. (...) pa mu je rëko dā, .. aəak mu níje cr̀veno, ak ga ne svìrbì da .. sùmnjā da je, na primjer, konjunktivitis (...)

143. Kâžu da djéte kad .. gā > .. kad se šêtaš, da se ùmīri.

Upotreba se vremena (i načina) razlikuje u izričnim, upitnim i zahtjevnim rečenicama prijekaza u neupravnom govoru. U zahtjevnim rečenicama dolazi prezent, kojemu u originalu odgovaraju imperativ i prezent. ${ }^{74} \mathrm{U}$ upitnim je rečenicama, a tako i u izričnim rečenicama iza većine predikatnih markera, pojednostavnjeno rečeno, ono glagolsko vrijeme koje bi bilo u originalu ${ }^{75}$. Doduše, kao što je poznato, vjernost originalu općenito nije osobito velika, pa nije zgodno opisivati upotrebu vremena u prijekazu pomoću odnosa prema originalu, tim više što nam original najčešće nije ni poznat. Osim toga, ako bismo uzimali u obzir referentnu točku po kojoj se orijentira glagolsko vrijeme u neupravnom govoru, bolje bi ga bilo uspoređivati s vremenom u upravnom govoru nego s vremenom u originalu. Ipak, smjelo bi bilo tvrditi da se vrijeme u ne-

${ }^{74}$ Sasvim rubno je moguć i perfekt koji odgovara originalnomu perfektu, u rečenicama kao: Rëko ti je da se nísi mïcao. (original: Da se níje mïcao!).

75 Sličnu formulaciju nalazimo u Forsyth 1970: 69. Doduše, ondje se upotrebljava termin original direct speech jer se upravni govor ne razlikuje od govora koji nije prijekaz, iako upotreba vremena u upravnom govoru i govoru koji nije prijekaz, zapravo nije sasvim ista. Naime, $u$ govoru koji nije prijekaz, vrijeme se primarno orijentira prema trenutku govora, dok se vrijeme u upravnom govoru ne orijentira prema trenutku prijekaza, nego prema trenutku originalnoga govora, koji može biti i fiktivan ili potencijalan. 
upravnom govoru orijentira prema originalnim koordinatama na jednak način kao u upravnom govoru, osobito ako se uzme u obzir da se u neupravnom govoru sva ostala deiksa orijentira prema koordinatama prijekaza. Točnija je formulacija da se glagolsko vrijeme u prijekazu pri neupravnom govoru orijentira prema vremenu glagola govorenja i sličnih glagola, tj. da se upotrebljava relativno i sintaktički interpretira kao istovremenost, prijevremenost i poslijevremenost $\mathrm{u}$ odnosu na vrijeme glavnoga glagola ${ }^{76}$, dok se $\mathrm{u}$ upravnom govoru na temelju širega konteksta potpuno preuzimaju originalne koordinate. Međutim, opisan slučaj vrijedi za glagole govorenja i neke slične predikate, ali ne vrijedi sasvim za glagole percepcije, koji uvode samo izrične rečenice. Naime, uz glagole se percepcije glagolsko vrijeme u neupravnom govoru nekad upotrebljava relativno, a nekad apsolutno. Originalnomu futuru u prijekazu uz takve glagole odgovara futur, pa se može reći da se futur uz njih upotrebljava relativno. Naime, futur označava potencijalne radnje, a ne realne, pa bi zamjena futura prezentom ili perfektom, koji označavaju realne radnje, značila predstavljanje nečega potencijalnoga kao da je stvarno, tj. falsificiranje ${ }^{77}$. Međutim, originalnomu prezentu, ako je riječ o radnjama koje su u trenutku prijekaza prošle, u prijekazu odgovara prezent ili perfekt, pa se može reći da se perfekt u tom slučaju upotrebljava apsolutno. ${ }^{78} \mathrm{Kad}$ je prošlo vrijeme već u originalu, ono je uz takve glagole i u prijekazu, i u tom slučaju između apsolutne i relativne upotrebe nema nikakve formalne razlike, pa upotrebu nije potrebno određivati kao relativnu ili apsolutnu ${ }^{79}{ }^{80}$ Glagol čüt sâm po sebi ne ukazuje jednoznačno na prenošenje verbalne obavijesti, pa u vezi s tim i djelomično apsolutnom upotrebom vremena neupravni govor uza nj može graničiti s priopćajem činjenice, a donekle slično vrijedi i za druge spomenute glagole percepcije.

${ }_{76}$ O terminu sintaktička interpretacija vremena (za razliku od deiktičke) v. Падучева 2010: 340.

77 Doduše, falsificiranjem bi se mogli smatrati i mnogi drugi slučajevi nevjernoga prenošenja teksta originala, ali valja imati na umu da nisu svi dijelovi originalnoga teksta jednako bitni, tj. da nisu sve varijacije između originala i prijekaza jednako dopustive.

78 Za razliku između relativne i apsolutne upotrebe uz ove glagole usp. sljedeće primjere: $A$ tî si tëk säd dòšô? Dànas je vëč ponèdjeljak, a jâ sam čùo da češ dôč u sùbotu.; Dïje Slávko? Kod zubára je. > Čüo sam da si bïo kod zubára. Ï.. käko je bílo? ili: Ma krénio sam jâ jùčè dò tebe, al sam pútem srëo tvôg bräta i òd njega sam čùo da si kod zubára, pa sam se vrátio küč. U posljednjem je primjeru referentna točka zadana događajem koji se pripovijeda. Čuo sam s apsolutnim perfektom u takvim je primjerima po značenju blisko oblicima saznao sam, znam, a s relativnim prezentom izrazu rekli su mi.

79 Takva je situacija s originalnim futurom prezentom i perfektom u slučaju kad vrijeme originala prethodi vremenu prijekaza. Međutim, ako vrijeme originala i radnji koje se spominju u originalu, slijedi vremenu prijekaza, u prijekazu se umjesto originalnoga prezenta i perfekta ne upotrebljava futur, nego i uz glagole percepcije uvijek dolaze relativno upotrijebljeni prezent $\mathrm{i}$ perfekt, usp. Ako čüješ da me nêma kòd kuče / da sam òšo do grâda / da sam se pröpio, nè vjeruj.

80 O sličnoj ovisnosti upotrebe vremena o tipu uvodnoga predikata u ruskom usp. Forsyth 1970: 69 sqq. i osobito Barentsen 1996: 20 sqq. 


\section{Priopćaj činjenice}

Pri upravnom govoru original, kao što je rečeno, reproduciramo kao svojevrsnu repliku i nerijetko ga u većoj ili manjoj mjeri insceniramo. S tim se u vezi u upravnom govoru često uvelike gubi veza sa situacijom prijekaza jer se uživljavamo i adresate prenosimo u originalnu situaciju. U neupravnom se govoru original prepričava, barem većim dijelom, iz perspektive situacije prijekaza, ali se veza s originalom pri tom ne gubi jer se odnos prema originalu naglašava vrlo jasnim i višestrukim markiranjem prijekaza (jednim od markera prijekaza, $\mathrm{tj}$. odnosa prema originalu, $\mathrm{u}$ neupravnom govoru možemo smatrati i relativnu upotrebu vremena). Međutim, u priopćaju se činjenice gubi veza s originalom zato što prekazivaču nije bitna. Drugim riječima, prekazivač u slučaju priopćaja činjenice ono što mu je netko rekao, prezentira kao činjenicu za koju on jednostavno zna. Izvor toga znanja nije osobito bitan, ali se on može navesti kao uzgredna napomena, npr. rëko mi je X. $Y$. (unutar ili na kraju prijekaza) ili Znâš štä sam čüo? (na početku prijekaza) i sl. Adresat često može o izvoru zaključivati i na temelju vlastitih znanja, konteksta i situacije. Nekad su takvi zaključci vrlo pouzdani, nekad su samo nagađanja, a u nekim slučajevima adresat uopće ne može biti siguran da je posrijedi prepričavanje diskursa. Cjelokupna je deiksa u priopćaju činjenice, razumije se, orijentirana isključivo na situaciju prijekaza. Isto tako, u prijekaz se ne prenose nikakvi elementi načina priopćaja. O iznimkama od tih dvaju pravila v. niže. S obzirom na svoju funkciju priopćaj činjenice ima nekoliko bitnih ograničenja u odnosu na upravni i neupravni govor. Prvo, u priopćaju se činjenice prepričavaju samo stvarni i fiktivni originali, dok se nulti i potencijalni originali ne prepričavaju. Doduše, i fiktivni je original pri priopćaju činjenice donekle ograničen. Naime, o priopćaju je činjenice s fiktivnim originalom riječ ako netko släžē i kao izvor uzgred spomene da je to što je rekao, doznao iz nečijih usta ili nečijega pera, ili ako se takav izvor jasno podrazumijeva iz konteksta i situacije. Ako se pak izvor ne navodi i ne podrazumijeva, onda je riječ jednostavno o laži, a ne o priopćaju činjenice s fiktivnim originalom. Drugo, ponavljanje vlastite izjave bez naglašavanja odnosa prema originalu nema smisla smatrati prepričavanjem diskursa, a ni obavještavanje adresata o onom što su sami rekli upravo kao o činjenici, a ne kao o njihovoj tvrdnji, nije osobito uobičajeno, iako je moguće, pa se priopćajem činjenice prenose gotovo isključivo izjave trećih lica. Treće, osnovu originala mogu činiti samo tvrdnje, a ne zahtjevi i pitanja. Doduše, sam original može sadržavati prijekaz, koji pak može sadržavati i pitanje i zahtjev, a u tom se slučaju u priopćaju činjenice mogu naći svi elementi koji se nalaze u prijekazu koji je sadržan u originalu: deiksa koja se ne orijentira na situaciju prijeka- 
za, zahtjevi pitanja, razni ekspresivno-dijaloški elementi i drugi elementi načina priopćaja. Premda rekurzivnosti prepričavanja diskursa u ovom istraživanju nije posvećena osobita pozornost, smatram da se o njoj i bez detaljne analize može reći sljedeće. Pri rekurzivnom su prepričavanju diskursa ostvarive sve zamislive kombinacije tipova prepričavanja diskursa, ali se, barem sudeći po primjerima, tipovi prijekaza najčešće redaju po pravilu da se pri kombinaciji više tipova prepričavanja diskursa neupravni govor obično nalazi unutar upravnoga, a upravni unutar priopćaja činjenice, usp. 7. i 144. primjer, gdje se priopćajem činjenice uvodi upravni govor koji sadrži neupravni govor (doduše, u 7. se primjeru priopćajem činjenice uvodi i neupravni govor), 145., 146. i 153. primjer, gdje se priopćajem činjenice uvodi upravni govor, te 70. primjer, u kojem neupravni govor sadrži upravni govor. Od rekurzivnosti prepričavanja diskursa i umetanja jednoga tipa u drugi valja razlikovati kombiniranje tipova prepričavanja diskursa, o kojem će biti riječi u idućem odjeljku.

144. (...) Tô Nèvena i Mislav nísu čüli, o plàvuši, sölidno ònō käo. Kad se plàvuša zapòslila u hotèlu kao domàčica > spremàčica > kao söbarica, jèl. I säd ònō zàzvoni telèfōn, ono ügledna ösoba, gospòdin, jèl, zòvē. Dobrovëče ovaj, dobrovëče, kâže. Mòliču vas ljêpo, kâže, stôl za ösam ösoba .. bi narúčio, kâže. Òpēt si, kaže, tî.. òna njëmu. Jesam ti več pêt pútā rèkla da jâ nè rādim na nämještaju.

145. Käk je ònāj vïc príčala... Òbūko dvê drugàčije cìpele, jèdnu smëđu jèdnu cr̂nu. Kâže mu šêf, dê idi tô küči presvúci. Kâže ôn, pa štä ču îč presvláčit, kòd kuče su mi ìste tákē.

146. Švërcali su Mújo i Háso tvörove. Jel znáte tô? — Në znamo. — Švërcali su tvòrove preko grànice i säd në znaju dì da ih säkriju. I kâže Mújo Hási käo, pa nê znam, käo, äjd sàkrī > sàkrī ga u gäče. Käže òvāj, ma néču, smr̀dī. Kaže ovaj, ma nëk cr̈kne.

147. Jèdna > jèdan brâčni pâr, kòlkō plâča stân? — Dvjësto dvàest ëura mjësečno. - Dvjësto dvàest ëura u zgrädi. - Dvjësto dväest ëura, Mìslave, plâča sämo ovaj pödstanarski žìvot.

148. Ma narúčila Jäsna, kao näzvala po dánu kao Marinëlu jùčē, da Marinëla (...) Čüla je od Vësne frìzērke da ìmā tämo bàtkōva jëftino i štä jâ znâm tê fóre käo. Da Marinëla kûpi. A säd ti išle Jèlena i Marinëla, štä?, na kölodvor prì̄o. - Dâ. - Tû zbog bùsa tô štä jâ znâm vâmo-tämo, pa su išle rêžje pláčat nëke, tämo Märinu, nèbitno, vâmo-tämo. Kad su vëč bíle u grádu, štä čemo säd ič pönovo u Gùnduličevu, neg su òtamo ödma tô üzele.

149. A dòšla òna u trgòvinu, ìmala dvê ï po kúne. A pâr pût je övū .. > dâ, pa joj òvā dòdā, a njôj vëč dosádilo. Dâ dvê ì po kúne, kâže òna, Nâdo, štä trëbaš. 
Kâže òna, pöšto vam je ònāj kìnder .. pïngu. (...) Kâže òna, štä češ? Pä svejèdno mi je. Pa očeš tâj buëno ili? Pa svejèdno mi je, kâže. Käd në, jâ vïdim dvê ï po kúne: dâ nôj je svejèdno, da jâ dòdām. Níje joj dála. (...) A níje joj dála zàtō što je rèkla 'dâj mi'.

150. İmām jèdnu kolègicu, òna je .. pa òna säd vëč dvàes gödina sìgurno u bráku. Kaže òna, nè dāj se vï̌se rëzat. Kaže, mëne su izrezali na svë strâne, $i$ òpèt ništa. A stvárno, jädna žèna i u Zágreb i .. jel rèkla čäk i u Rjéku da je išla; ma në znam, $i$ üzduž $i$ pöpreko su je izrezali, svë u rédu, i ni dân-dànas žèna nêma. Nači, bila jedno čètri il pêt pútā na ùmjetnoj oplódnji.

151. Štä ${ }^{81}$ - Ma Äni nëšto trëa, al nè može > trëba nëki rècept, a nè može me nàzvat.

Priopćaj činjenice ponekad sadrži neke elemente koji više ili manje implicitno upućuju na to da je riječ o prepričavanju diskursa, a ne o činjenici o kojoj smo se izravno osvjedočili. Takvo je ponavljanje markera käo ili oznake koje upućuju na to da prepričavamo nečije planove, kao što su kondicional trećega lica i glagol kòntat u sljedećim primjerima. Prepričavanje diskursa u takvim primjerima graniči s polunavođenjem.

152. U ponèdjeljak ìmā käo tâj nëki zàdnjī tëst käo .. zà tāj nëki, në znam, tô što ôn če säd rádit, vëb nèšto, $i$ önda käo bi, ak bi trëalo tô svë bït okêj, > täk da bi ôn vàljda .. do kräja gödine önda > od pètnaestog do kräja gödine käo bïo na gòdišnjem óvdje $i$ od .. pr̀vōg tjëdna vàljda u pr̀vōm mjësecu bi pöčeo.

153. (...) I tô na kràju, kak smo príčali nëšto, znâš, o tîm pòslovima, tô jâ ispríčala tôj, i òvā kâže 'Â, pa tô je mòja Sänja!, Ïsuse, nè moš vjërovat!', käo, ònō, njêna prijatèljica. Jöšs se käo nije htjëla ìsto ni prijávit jēr je, ònō, köntala stô pösto je nàmješteno, i òvā ju nàterala, dâj prijávi se, nêmaš štä izgùbit, òdi na ràzgovor, nâs.

\section{Polunavođenje}

Polunavođenjem ovdje nazivam donekle nehomogen tip prepričavanja diskursa koji ima sljedeće osnovne opće osobine: 1 . lice se, a većinom i ostala deiksa izražena leksičkim sredstvima, ravna prema koordinatama prijekaza; 2. vremenska se deiksa ravna prema originalnim koordinatama, a sam prijekaz ili njegov kontekst može sadržavati i neke druge osobine iz kojih je vidljiva veza s originalom; 3. prijekaz se ili ne markira predikatnim markerom ili je s njim povezan parataktički. Ovaj se tip upotrebljava rjeđe od neupravnoga govora, a

${ }^{81}$ Pitanje se odnosi na sadržaj netom završenoga telefonskoga razgovora informantice s Aninim bratom. 
ima obilježja svih triju dosad obrađenih tipova prepričavanja diskursa. On se obrađuje na ovom mjestu, tj. poslije njih, upravo zato da bi se lakše mogao uočiti njegov odnos prema ostalim tipovima. S priopćajem ga činjenice zbližavaju sljedeće karakteristike: 1 . često nema predikatnoga markera prijekaza; 2 . većina se deikse orijentira prema koordinatama prijekaza; 3. služi za prepričavanje samo stvarnih i fiktivnih originala; 4. njegova se upotreba može smatrati reduciranom s obzirom na deiksu, jer ga u slučaju kad se koordinate originala i prijekaza poklapaju, nije moguće razlikovati od upravnoga govora. Međutim, ovaj tip ima i više osobina koje ga razlikuju od priopćaja činjenice, a zbližavaju ga s upravnim i neupravnim govorom: 1. glagolsko se vrijeme orijentira prema originalnim koordinatama, a takvu orijentaciju mogu imati i neki elementi leksički izražene deikse (npr. riječ säd); 2. prijekaz može sadržavati elemente načina priopćaja (takvih je elemenata znatno manje nego u upravnom govoru); 3. prijekaz može sadržavati upitne i zahtjevne rečenice; 4. prijekaz može sadržavati tvrdnje koje prekazivač očito ne smatra činjenicama; 5. markiranje prijekaza, ako ono postoji, sličnije je markiranju upravnoga i neupravnoga govora nego napomenama o izvoru uz priopćaj činjenice; 6 . kontekst prijekaza nerijetko vrlo jasno upućuje na odnos prijekaza s originalom (recimo, kad je iz konteksta jasno da je prijekaz u polunavođenju jedna od replika u dijalogu ili općenito nečija izjava). Na temelju navedenih osobina moglo bi se zaključiti da je polunavođenje nešto između upravnoga i neupravnoga govora s jedne strane $\mathrm{i}$ priopćaja činjenice s druge. To ipak ne bi bilo sasvim točno. Kad se polunavođenjem prenose izjave koje prekazivač nikako ne smatra činjenicama, te pitanja i zahtjevi, ono ima malo veze s priopćajem činjenice, dok mu u slučajevima kad je original tvrdnja o nekom činjeničnom stanju, može biti znatno bliže. Naime, iako se polunavođenje ovdje obrađuje kao jedan tip prepričavanja diskursa, ono je, kao što je rečeno, relativno heterogeno, pa ga je moguće promatrati i kao nekoliko slabo razgraničenih tipova. Ako daljnja podjela na tipove i ne bi bila moguća, polunavođenje bi se moglo podijeliti na tri funkcionalna podtipa koji se ne daju strogo razgraničiti. Jedan se od takvih podtipova upotrebljava u dijalozima i po tom je sličan upravnomu govoru, a njegovu jezgru čine primjeri kao 154. i 155. Drugim se podtipom navode nečije kraće tvrdnje izvan dijaloga, što ga čini sličnim neupravnomu govoru, a jezgra su toga podtipa primjeri kao 160., 163. i 164. Pomoću trećega se podtipa na sažet način navodi duži niz činjenica koje proizlaze iz originala, pri čem se ne prekida veza s originalom. On je sličan priopćaju činjenice, a njegovu jezgru čine primjeri kao 169. Zajednička je osobina većine slučajeva polunavođenja to da je veza s originalom slabija nego pri upravnom i neupravnom govoru, a jača nego pri priopćaju činjenice. To svakako vrijedi pri usporedbi pojedinih funkcionalnih podtipo- 
va polunavođenja s odgovarajućim tipovima prepričavanja diskursa. Polunavođenjem se koristimo kad se referiramo na nešto što je rečeno više puta, a bitno nam je da prenesemo smisao rečenoga, kad sažimamo neki original i prenosimo njegov smisao, ali se $\mathrm{u}$ isto vrijeme na taj original želimo referirati, i u sličnim slučajevima dekonkretizacije originala. Polunavođenjem se bez predikatnoga markera prijekaza nerijetko prenosi izjava prema kojoj prekazivač ima negativan stav ili se prema njoj odnosi s ironijom. Markeri su prijekaza pri polunavođenju, ako postoje, perfekt i prezent od rëč i čestica käo. Drugih markera u analiziranoj građi nema. Prezent je glagola rëč u nekim primjerima ekspozicijski, a u nekim historijski. Neki su od navedenih markera karakterističniji za upravni (nula, käo, historijsko kâžem), a neki za neupravni govor (perfekt od rëč i ekspozicijsko kâžem). To je još jedan od pokazatelja da polunavođenje ima osobine svih triju prethodno obrađenih tipova prepričavanja diskursa, tj. da su različiti primjeri polunavođenja više ili manje slični nekomu od triju prethodno obrađenih tipova prepričavanja diskursa. Uz sljedeće primjere usp. i 17., 22., 93. i 94. primjer.

154. Kâže döktor käo, .. vî môrate, kâže, göspođo, säd kad dôđete... Në käo .. nêma mjësta, na pòmočni lëžaj če lëč. Kae òna, kòji pòmočni lëžaj? Kâže, nïkaki pòmočni lëžaj. Kâže, pa önda, käo ovaj, mälo ste bölje, imā i lošiji. E òna ïde küči. Dòbro ìdete küči: tô svë môrate ùzimat: tablète $i$ vâm-tämo, inèkcije je dobivala: môrate jëst, kâže, vöče, .. mêso, pòvrče, jèl tô svë.

155. Trážio je tätu mètar, pa su njîh dvòjica mjërili širinu .. hàustora i širìnu njègovog àuta jel ga je zanímalo jel möže uparkírat àuto, .. pa dok su òni òšli, s öbzirom da se parkíro täm kod súsjede, .. si iżmjerit tô, jâ njû pîtam käk se zòve,, jâ zabòravila: nè zna ni òna. Jëbō te, reko, bäšs si pämetna.

156. Né misim da trëba làgat ili në znam štä, al önda s- > ak se nè moš angažirat, réci i doviđénja, a në .. sëam pútā rëč kak je > käk je u gûžvi, i käo: níje aəa > strášno je pò tōm tlócrtu näšem koji ìmāmo, ne odgòvāra stvârnom stánju, i pòkušali su i precrtávat i docrtávat i vâmo-tämo, $i$ jëdnostavno nəə$>$ käo nè može se dočárat tô kak jê, i môra òna, môra òna pòslat svòje dèčke, pòslače òna njîh, čìm > čìm käo ùhvate vrëmena, na svë strâne su joj käo, pa če ih pòslat da tô pòsnīme da se tô nàpravi. I donèsē mi báner: znači, trî mjëseca stòji küča na òglasu, a òna mëni donèsē nakon trî mjëseca da nàkačim báner nà kuču.

157. Mâ, ôn tô glëda, imā dëset gödīna stâža, ôn bi säd trëbo îc kúmit-mòlit, ovo-ònō, rádit za minimálac: .. jel zàtō završio fakùltêt ì tä dä ì tà bä.

158. Jâ käžem, pa štä râdi Jöka? - Â, kâže, Jöka hr̂̌ěe. - A tî? - Pa ëto: òna nïkad nè spāva käo, znâšs. 
159. I znâči, zà tō se trëa priprémit i zà to trëaš ùzēt jöš .. ljúdī, razùmjēš... Òvā nêce ni da cuüje: o- > käo, näma möže nëko uskákat...

160. (...) A s drüge stránē nas vrjêđa i glúpi smo i klìjentima komèntīra kak smo glúpi i në znam štä.

161. Pò njemu se mî nismo pòsvađali, i nè vidi uöpče zäšto: sämo smo razgovárali.

162. Višnja mòja mëne jèdan da > jèdno vëče zvála: idē küči kâže, .. käo, pròlazi i na čòšku vïdi njëga s nëkim lìkom.

163. A cǜjem, kâže mi mäma tvòja da si tî ìsto pütovo u ponèdljak küči, jèl? (...) I bäš s tvòjōm mämom prîčam nëki dân, i kâǎe, dòšō si i tī bäš küči tâj dân.

164. Dodúše, dä, Àntun öče da büde cürica: ôn kâže, ôn bi vòlio ìmat cüricu.

165. Jùčē prîča: Jâ eto në znam käko ču dïgnut miròvinu. Snjêg je vàni, a jâ sam môj pîn zabòravila. A jâ nè mogu îč u bànku. A Marko je rëko, ôn če îc sa Zdénkom.

166. Pr̀vō je rëko, nêče îč, a önda je rëko, äjd ïdem, kaže, mälo.

167. A baklávu pèčè več dvâ mjëseca ${ }^{82}$ i na kràju níje ispekla. — Nâjprije je rèkla, kúpila je òrahe, onda je Mârko pòjeo òrahe, .. önda je òpēt razmišljala...

168. (...) Jel ôn je rëko, käo imā dvöje djècē i käo nâda se da če se šírit.

Polunavođenje je teško razgraničiti od ostalih tipova prepričavanja diskursa. Problem razgraničavanja polunavođenja i neupravnoga govora $u$ dužim prijekazima s izričnim rečenicama već je spomenut u dijelu o neupravnom govoru. U takvim se slučajevima može pretpostaviti ili neupravni govor koji u dužim prijekazima funkcionira po nekim dodatnim pravilima, ili kombinacija neupravnoga govora i polunavođenja. U slučaju je zahtjevnih i upitnih rečenica razgraničavanje još teže, a može se temeljiti, čini se, jedino na uvođenju ili neuvođenju takvih rečenica predikatnim markerom. Već je spomenut i problem razgraničenja polunavođenja od upravnoga govora u slučajevima kad se koordinate prijekaza i originala poklapaju. Naravno, nije uvijek moguće ni razgraničenje od priopćaja činjenice. Problemi razgraničenja tipova prepričavanja osobito dolaze do izražaja u dužim prijekazima kao što je sljedeći u kojem se može pretpostaviti kombinacija upravnoga govora, polunavođenja i priopćaja činjenice, ili u primjerima problematičnih dužih prijekaza obrađenih u dijelu o neupravnom govoru. Naime, pri proučavanju pojedinih tipova prepričavanja diskursa uvijek valja imati na umu da između pojedinih tipova nema jasne granice, dok su varijacije i kombinacije brojne.

${ }^{82}$ I odsječak je $a$ baklávu pèčé več dvâ mjëseca svojevrstan, rubni tip prepričavanja diskursa jer se njime želi reći da osoba govori o tom da će ispeći baklavu. 
169. Mëne je nà tāj drügi räzgovor kad sam išla na še- > u šečerànu, vòzila nëka tàksistkinja .. i käo əə säd òna mëni 'kàko ste mi vî dànas', hehe. I jâ ònō .. näpeto. - Zäšto? - I säd jâ njôj kâžem, pä, ïdem kao na räzgovor. - Ahâ, dòbrodòbro. Käo, pa štä?, pa nije bäš ni glëala nätječaje, râdi säd tû, u tôm Kamëu vëč, në znam, petnaéstak dánā, rádila je u Vélikoj Britāniji i dòšla je na gòdišnji. ${ }^{83} \mathrm{Na}$ trî tjëdna .. i jëdnostavno je onäk, odlúčila da se nêce tämo vrátit $i$ da idè tû na prìō što ùvati. Î ëto: döbila je pòsao .. i kâže, nêče se ni vrátit säd döle; kâže täk je käk je, täk da ònō... Žéna, ònō, në znam, ìsto .. četrdesétak gödina, kaže, nísam üdana, nêmam djèce, mògu rádit koju göd smjënu hòču, nïgdje nè žūrim... Ájde, reko, dóbro. Tämo je rádila u nëkom stàračkom.. Käo jê dòbra lóva i svë, i mïsla je, ak vëč idē vân, nêče ni Îrsku ni Njèmačku, idē nëgdje di je bäš ònō lóva-lóvalóva. I käo òšla u Vëliku Britāniju .. i ovāj... Äl kâže, đàba tîh pâra, kâže: ëm pòsō .. za popizdit, ëm, kâže, nè moš, kâže, nè moš tî: tvòji ljûdi su tû, Ösjek .. je tû, a säd .. täk je käk je. A ìmā žèna dvâ fakultéta: ekonòmiju i në znam štä mi je jöš rèkla.

\section{Oznake skraćivanja i približnosti u prepričavanju diskursa}

Prepričavajući diskurs, prekazivač može iz različitih razloga svjesno skraćivati original. Takva se kraćenja ne moraju uvijek naznačavati, ali nekad je to nužno. Tako je kad se pri kraćenju izostavlja neki dio rečenice bez kojega bi rečenica bila gramatički nepotpuna ili bi bila potpuna, ali bi imala drukčiji smisao nego u originalu. U tim se slučajevima kao markeri kraćenja, odnosno kao zamjena za punoznačne riječi, upotrebljavaju izrazi s pokaznim zamjenicama kao što su (tâj,) tâj i tâj, (tô,) tô i tô, tàkō i tàkō ili suprotstavljene pokazne zamjenice kao òvō ... ònō, ovàkō ... onàkō, vâmo ... tämo. Pri ovakvim se kraćenjima mogu upotrebljavati i pojedinačne pokazne zamjenice, npr. tô, tàkō, tämo. Pri izostavljanju većih dijelova teksta ili približnom prepričavanju kraćenje se ili ne naznačava ili se upotrebljavaju već navedeni izrazi ili se upotrebljavaju nešto drukčiji izrazi. Riječ je s jedne strane o onomatopejskim izrazima kao blâblâblâ, a s druge strane o izrazima kao òvō-ònō i vâmo-tämo, a drukčiji su izrazi rjeđi. Posljednji izrazi ne označavaju samo kraćenje, nego i približnost, a služe i kao poštapalice, pa se njihova upotreba dosta razlikuje od govornika do govornika $^{84}$. Njima je po značenju bliska i čestica käo, koja je obrađena u prethodnim poglavljima, a uz to što upućuje na približnost služi i kao marker prijekaza. Svi se spomenuti izrazi upotrebljavaju i izvan prepričavanja diskursa i zaslužuju da budu opisani detaljnije nego u ovom kratkom prikazu. U sklopu prepričavanja diskursa ovi se izrazi najčešće sreću u prijekazima u upravnom go-

83 Interpunkcija prati intonaciju, a ne smisao rečenice.

${ }^{84}$ Neki ih govornici gotovo ne upotrebljavaju. 
voru, ali dolaze i u prijekazima ostalih tipova. Uz sljedeće primjere usp. i 93., 107., 139. i 157. primjer.

170. Ê, a jes vïdio sìnoč kad je pöčela spíku?, pa nïkad... Krêne jèdno, pa tô ti je tàko, pa sam döbila òvō, pa sam krénula, .. e pa sam dòšla do sàndučiča preko hödnika, a òno svë üsko, pa sam üzela tû kòvērtu, tâ kòvērta je onäk širöka... Â jëbō te...

171. Ê, tô ti je bíla cjêla prîča oko pîna njênog. - (...) Kâže, i önda blâblâblâ, ošla òna u bánku ì tô, tô $i$ tô, i rèkla, në zna pîn käo, pa su òni u bánci upísali podátke (...) To döbiješ küuci, jer täm pî̌se 'pîn tâj, tâj i tâj, pa vas mölim, ùništite ili bácite', vâmo-tämo.

172. Ê, mî nëšto ònō .. príčali, käo tô $i$ tô, a ôn säsvim lüpio. — Nëšto, jèl, štä jâ znâm, òvō?: kâže, dâ, žillavo je.

173. Č̈m je zaviršila fakùltēt, .. svätovi, òvō-ònō... I òna je sëbi, ònō, zàcrtala, znâs: do tê i tē gödine jèdno djéte, do tê ì tē gödine drügo djéte, az àuto ovàkī, àuto onàkī... Pa su önda üzeli tâj vëliki stân, dā > trídeset gödina dïgli krèdìt, vâmo-tämo.

174. Pâ önda mi svï príčaju, .. 'à òni su ti ovàkī, òni su svì ovàkì', ono bòlì me üvo, i òvī su mi bíli ovàkī i onàkī: öpče se ne zàmāram s tîm.

175. Jer ti Mára u stvári, òna je i dösta drága žèna ìsto oväk, nego òna ti tô prètvori, üvjek komplììira: jôj käk če òna kad pöčne rádit?, käk če òvō?, kö če ti djéte?, kö če tô, tô? (...) Al òna znâ iskomplicirat tô: jôj òvō, jôj ònō, jôj ònō, jôj ònō.

176. İšla sam kod nëkog $u$ Vâlpovo döktora: kâže ôn, môrate î̌ u Zágreb na operáciju. - Pa zäšto jâ tô opèrīram? - Pa da vïdimo òvō, pa da vïdimo ònō. $P a$.. čôvječe, štä opèrīram?: në znaš ni štä mi râdiš.

177. Ïako, äj, jèdino što mi je bílo okêj, kad je on iskomentírō, ahâ, käo oväk ödokativno imā jèdno pètnaes-dvàes tǐšca èura ulágānja bläablâ: .. käo käk stòjīte s cjénōm, odnosno kòlkō ste flëksibilni, önda je òna rèkla: hä, čûjte da nêma tòlkō ulágānja, önda në bi tòlkō köštala, önda bi bíla sküplja.

178. A u ponèdeljak üjutro sam dòbila mêjl da je pòsao döbio, në znam, Vèdran bälälä: prèzīva se ìsto kô direktòrica firme.

179. Dâ, ôn je rëko mëni, käo, jâ sam razòčāran käo: razòc̄āran sam sa svíme, razòčāran sam sä sobom, òvō-ònō.

180. Kad jèbō te život, i ôn zòve mämu, dë mi säm mälo mämu. Mäma, ònō, vâmo-tämo, Bècingeri tî, vâmo-tämo, jel jöš ìmāš tû pünomoč, vâmo-tämo. Käko ne: zäšto? Pa ëvo, kâže näš İvica tû (...)

181. Kad je önda Milénko njû, nâš ònō, vâmo-tämo: ònō, .. mïslim, .. ùmjereno, šăli se, dèčko ${ }^{85}$ nëšto, vâmo-tämo (...)

${ }_{85} \mathrm{Tj}$. pita je ima li dečka, ili nešto u tom smislu. 
182. (...) pa käo ònō nâš: čùli smo se əə käo kàkā je tämo situácija i tô, jël. Mä tämo käo nè moš ònō .. bez gäzde nï̌st, ònō, nâšs.

\section{Zaključak}

Ciljevi su ovoga rada bili stvoriti kakav-takav teorijski okvir za opis prepričavanja diskursa i ukratko opisati prepričavanje diskursa u osječkom govoru, čime bi se ujedno provjerila upotrebljivost teorijskoga okvira i otklonili neki njegovi nedostaci. U nastavku se navode neki od rezultata, koji bi trebali ukratko predočiti u kojoj su mjeri ti ciljevi dostignuti. Neki su rezultati povezaniji s teorijom i, kako se nadam, relativno široko primjenjivi, dok su drugi povezaniji sa samom analiziranom građom.

Smišljen je termin prepričavanje diskursa, prvi jedinstveni domaći naziv za upravni i neupravni govor te bliske pojave. Prepričavanje je diskursa prilično precizno definirano prema svojoj funkciji i razmatralo se upravo u onom opsegu koji je zadan definicijom (tako je u opis uključen i priopćaj činjenice, tip koji u literaturi, koliko mi je poznato, dosad nije ni spominjan ni opisan). Stvorena je kratka teorija prepričavanja diskursa, u čijem se sklopu donosi niz pojmova koji znatno olakšavaju opis prepričavanja diskursa: original (stvarni, fiktivni, potencijalni i nulti) i prijekaz, koordinate i sadržaj, jezgra i ovojnica (orijentacija i način priopćaja) te markeri prijekaza (naziv je prikladan jer se prijekaz ne markira samo glagolima). Imenovana su te s formalne i funkcionalne strane definirana četiri tipa prepričavanja diskursa u usmenom osječkom govoru (upravni govor, neupravni govor, polunavođenje i priopćaj činjenice), a dani su i općeniti podaci o njihovoj relativnoj zastupljenosti u korpusu. Tipovi se detaljnije opisuju s obzirom na bitne karakteristike prijekaza kao što su orijentacija, način priopćaja i markeri te s obzirom na neke osobine karakteristične za pojedine tipove.

Sam opis osječkoga prepričavanja diskursa donosi više inovacija u odnosu na poznate opise, od kojih ću spomenuti samo neke ${ }^{86}$. Ističe se različitost funkcije pojedinih tipova prepričavanja diskursa i činjenica da oni nisu uvijek međusobno zamjenjivi. Kao jedna od funkcija upravnoga govora prepoznaje se i funkcija inscenacije te se ukazuje na upotrebu/prenošenje neverbalnih govornih vrednota pri upravnom govoru. Dosta je pozornosti posvećeno originalu te odnosu originala i prijekaza. Tako se utvrđuje da se tipovi prepričavanja diskursa razlikuju između ostaloga i s obzirom na tipove originala koji se u njima mogu pojaviti. Upozorava se na mogućnost varijativnosti deiksa/anafora/nominacija između originala i prijekaza i na mogućnost prenošenja diskontinuiranih origi-

${ }^{86}$ Neki se od sljedećih fenomena spominju u pojedinim opisima, ali ne i u većini, a i kad se spominju, obično se spominju samo uzgred. 
nala u jednom prijekazu. Odnos lica (i drugih deiktika) u originalu i neupravnom govoru objašnjava se na vrlo jednostavan i ujedno precizan način pomoću koordinata, odnosno orijentacije/perspektive u prijekazu. Zanimljive je rezultate dao i opis markera prijekaza. Uočava se drastična razlika u upotrebi markera prijekaza u različitim tipovima prepričavanja diskursa (između ostaloga i različitost tipova prezenta kâžem u upravnom i neupravnom govoru) kao i razlika u upotrebi različitih markera unutar pojedinih tipova prepričavanja diskursa. Osim predikatnih markera prijekaza obrađuje se i marker käo (pri čem se upozorava i na razliku između käo i kö), a obrađuje se i nulti marker te se određuju uvjeti njegove upotrebe u upravnom govoru. Opisuju se i pravila smjene govornika unutar prijekaza u upravnom govoru. Uviđa se također važnost oznaka skraćivanja i približnosti u prepričavanju diskursa te se skicira njihova upotreba.

Samo je po sebi razumljivo da ovaj rad ima i svojih mana i da neka ponuđena terminološka i druga rješenja vrlo vjerojatno nisu najbolja moguća. Ipak, ako on samo nekoga potakne da se bavi prepričavanjem diskursa i doprinese širenju spoznaja o njem, već time će ispuniti svoju zadaću.

\section{Literatura:}

Barentsen, AdriaAn AriJ. 1996. Shifting points of orientation in modern Russian. Tense selection in 'reported perception'. Pragmatics and beyond 43: $15-55$.

BARIĆ, EugENIJA I DR. 1997. Hrvatska gramatika. Školska knjiga. Zagreb.

Benić, Mislav. 2007. Osnovni podaci o osječkoj akcentuaciji. Filologija 48: $1-28$.

BenIĆ, MisLAV. 2017. Пересказывание дискурса на примере говора Осиека и окрестностей. 12. letno srečanje Združenja za slovansko jezikoslovje. Povzetki prispevkov. Ur. Repanšek, Luka; Šekli, Matej. Inštitut za slovenski jezik Frana Ramovša. Ljubljana.

BIČANIĆ, ANTE I DR. 2013. Pregled povijesti, gramatike i pravopisa hrvatskoga jezika. Croatica. Zagreb.

Brabec, Ivan; Hraste, Mate; Živković, Sreten. 1968. Gramatika hrvatskosrpskoga jezika. Školska knjiga. Zagreb.

Evans, Nicholas. 2013. Some problems in the typology of quotation: a canonical approach. Canonical morphology and syntax. Ur. Brown Dunstan; Chumakina Marina; Corbett, Greville G. Oxford university press. Oxford.

Forsyth, JAMES. 1970. A grammar of aspect usage and meaning in the Russian verb. Cambridge university press. Cambridge. 
Gortan, Veljko; Gorski, Oton; Pauš, Pavao. 1985. Latinska gramatika. Školska knjiga. Zagreb.

KaPOVIĆ, Mate. 2011. Čiji je jezik. Algoritam. Zagreb.

KaTIČIĆ, RADOSLAV. 1991. Sintaksa hrvatskoga književnog jezika: nacrt za gramatiku. HAZU. Zagreb.

Maretić, Tomislav. 1899. Gramatika i stilistika hrvatskoga ili srpskoga književnog jezika. Kugli i Deutsch. Zagreb.

Menge, Hermann. 2009. Lehrbuch der lateinischen Syntax und Semantik. Wissenschaftliche Buchgesellschaft. Darmstadt.

Plunguan, Vladimir AleKsandrovič. 2016. Opća morfologija i gramatička semantika. Uvod u problematiku. Srednja Europa. Zagreb.

RaguŽ, Dragutin. 1997. Praktična hrvatska gramatika. Medicinska naklada. Zagreb.

Renzi, Lorenzo; Salvi, Giampaolo; Cardinaletti, Anna (ur.). 2008. Grande grammatica italiana di consultazione. Vol. III. Tipi di frase, deissi, formazione delle parole. Il mulino. Bologna.

Silić, JosiP; Pranjković, Ivo. 2005. Gramatika hrvatskoga jezika za gimnazije $i$ visoka učilišta. Školska knjiga. Zagreb.

TeŽAK, StJePKo; BabiĆ, StJePAn. 2004. Gramatika hrvatskoga jezika. Školska knjiga. Zagreb.

БОНДАРКО, АЛЕКСАНДР ВЛАДИМИРОВИЧ I DR. 1987. Теория фУнкииональной грамматики. Введение. Аспектуальность. Временная локализованность. Таксис. Наука. Ленинград.

ДИБРОВА, ЕЛЕНА ИНноКеНТЬЕВНА I DR. 2008. Современный русский язык. Теория. Анализ языковых единии. Часть II. Издательский центр «Академия». Москва.

ЗАЛИЗНЯК, АННА АНДРЕЕВНА; ШМЕЛЁв, АЛЕКСЕЙ ДМИТРИЕВИЧ. 2000. Введение в русскую аспектологию. Языки русской культуры. Москва.

ПадУчевА, ЕлеНА Викторовна. 2010. Семантические исследования. Семантика времени и вида в русском языке. Семантика нарратива. Языки славянской культуры. Москва.

ПадУчеВА, ЕлЕНА ВиктоРОВНА. 2015. Коммуникативная структура предложения. Проект корпусного описания русской грамматики. http://rusgram.ru/ (pristupljeno 13. listopada 2017.).

ПоПОВА, ИРИНА СЕРГЕЕВНА. 2009. Прямая речь и цитирование как способЫ передачи чужого слова в устнопорождаемой речи. Вестник Иркутского государственного лингвистического университета 3/7: 65-69.

ШвеДОВА, НАТАЛИЯ ЮльЕВНА I DR. 1980. Русская грамматика. Наука. Москва. 


\section{Пересказывание дискурса на примере говора Осиека и окрестностей ${ }^{87}$}

\section{Резюме}

Под термином «пересказывание дискурса» (ПД) понимаются разные способы преимущественно или полностью вербального воспроизведения преимущественно или полностью вербальной информации, причём вербальная составляющая является обязательной, а посредником между оригинальной и воспроизведённой информацией, в случаях, когда оригинальная информация не фиктивная, не нулевая и не потенциальная, обязательно выступает человеческая память, в первую очередь долговременная. Проще говоря, ПД - это чужая речь в несколько расширенном виде. Лингвистические описания ПД, вообще говоря, довольно скудны. Этот факт можно хотя бы частично объяснить тем, что ПД сравнительно трудно вписывается в рамки, навязываемые большинством главенствующих грамматических теорий. Самая подходящая грамматическая теория для изучения ПД в отдельном языке - это, пожалуй, русская функциональная грамматика, так как ПД можно рассматривать как своего рода функционально-семантическое поле (вернее - часть более широкого ФСП эвиденциальности).

Настоящая работа преследует две цели: 1) пусть незначительно, но усовершенствовать теоретический подход к изучению ПД; 2) создать сравнительно обширное введение в ПД в говоре Осиека и окрестностей. Эти две цели дополняют друг друга, так как данные из устной речи жителей города Осиека послужили основой для создания теоретического аппарата, а теоретический аппарат в свою очередь помог описать эти данные. ПД понимается автором как процесс, включающий два основных этапа: оригинал (исходный дискурс) и пересказ (актуальный дискурс). Оригинал может быть фактическим (существующим), нулевым (явно несуществующим), потенциальным и фиктивным (выдуманным). У каждого этапа есть свои координаты (участники коммуникации, пространство, время и т.п.) и содержание (информация). Полное содержание оригинала состоит из ядра (суть сообщения) и оболочки (ориентация (исходный дейксис) и способ сообщения (экспрессивно-диалогические элементы, язык, диалектальные

87 Sažetak koji slijedi, prilagođena je varijanta sažetka moga izlaganja na 12. susretu Slavističkoga lingvističkoga društva (SLS), koji je objavljen u zborniku sažetaka izlaganja s toga susreta (Benić 2017). 
и паралингвистические особенности и др.)). Содержание пересказа - это не копия, а, как правило, более или менее неверное отражение полного содержания оригинала или его ядра. Пересказ часто содержит маркеры пересказа, которые бывают прямыми (глаголы речи, указания на исходных адресанта и адресата и др.) и косвенными (подражание речи оригинального адресанта, сохранение оригинального дейксиса и др.). Исходя из таких параметров, как типы возможных оригиналов, отношение оригинала и пересказа (ответ на вопрос, какая именно часть оригинала передаётся в пересказе), способ маркирования пересказа и др., можно выделять разные типы ПД. В осиекском говоре выделяются четыре типа ПД: прямая речь, косвенная речь, сообщение факта и полуцитация. Эти типы в настоящей работе описаны сравнительно исчерпывающим образом с формальной стороны; кроме того, делается попытка дать краткую функциональную характеристику каждого из них. В конце статьи вкратце упоминаются некоторые способы маркирования сокращённой и приблизительной передачи содержания оригинала в пересказе.

Ključne riječi: upravni i neupravni govor, hrvatski jezik, Osijek Ключевые слова: чужая речь, хорватский язык, Осиек 
